\title{
Science within the U.S. Geological Survey Florida Integrated Science Center (FISC): Applications, Integration, and New Opportunities
}

By the U.S. Geological Survey

Florida Integrated Science Center (FISC) Science Council

\author{
John Brock (St. Petersburg, Florida) \\ Tonya Clayton (St. Petersburg, Florida) \\ Bob Dorazio (Gainesville, Florida) \\ Terence Edgar (St. Petersburg, Florida) \\ Pam Fuller (Gainesville, Florida) \\ Bob Halley (St. Petersburg, Florida) \\ Brian Katz (Tallahassee, Florida) \\ Ben McPherson (Tampa, Florida) \\ Barbara Poore (St. Petersburg, Florida) \\ Bob Renken (Fort Lauderdale, Florida) \\ Ken Rice (Fort Lauderdale, Florida) \\ Eric Swain (Miami, Florida) \\ Peter Swarzenski (St. Petersburg, Florida) \\ Steve Walsh (Gainesville, Florida) \\ Eastern Regional Office \\ Tom Armstrong (Reston, Virginia) \\ Coordinator: \\ Lisa Robbins (St. Petersburg, Florida) \\ Ed Oaksford (Tallahassee, Florida)
}

U.S. Geological Survey Open-File Report 2005-1364 


\title{
U.S. Department of the Interior \\ Gale A. Norton, Secretary
}

\section{U.S. Geological Survey \\ P. Patrick Leahy, Acting Director}

U.S. Geological Survey, Reston, Virginia: 2005

Revised and reprinted: 2005

\author{
For sale by U.S. Geological Survey, Information Services \\ Box 25286, Denver Federal Center \\ Denver, CO 80225 \\ For more information about the USGS and its products: \\ Telephone: 1-888-ASK-USGS \\ World Wide Web: http://www.usgs.gov/
}

\begin{abstract}
Any use of trade names is for descriptive purposes only and does not imply endorsement by the U.S. Government. Although this report is in the public domain, permission must be secured from the individual copyright owners to reproduce any copyrighted materials contained within this report.

Suggested citation:
\end{abstract}

Robbins, Lisa, and Oaksford, Edward, 2005, Science within the U.S. Geological Survey Florida Integrated Science Center (FISC): Applications, Integration, and New Opportunities: U.S. Geological Survey Open-File Report 2005-1364, 26 p. 


\section{CONTENTS}

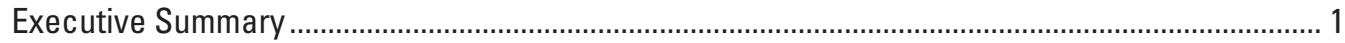

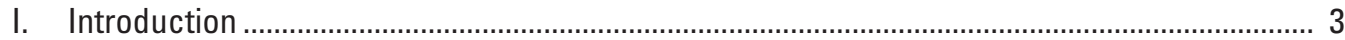

II. Discipline-Specific, Multidisciplinary, and Integrated Science in FISC ................................... 4

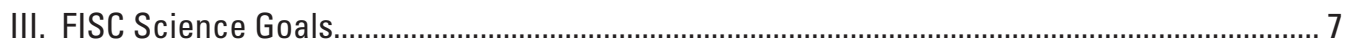

IV. FISC Core Capabilities and Continued Science Excellence........................................................ 8

Agricultural and Urban Impacts on Water Quantity, Water Quality,

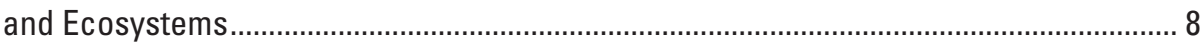

Conservation Science ........................................................................................................10

Contaminants, Pathogens, and Other Environmental Stressors ........................................11

Ecosystem History and Climate Change ........................................................................12

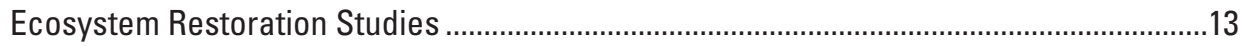

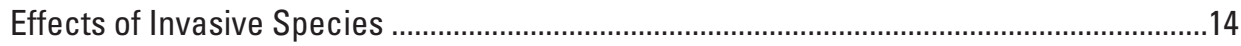

Interaction among Ground Water, Surface Water, and Ecosystems.................................14

Natural Hazards and Associated Coastal Processes .........................................................16

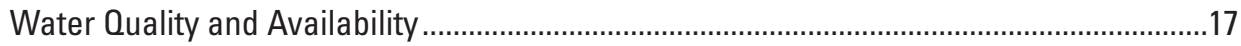

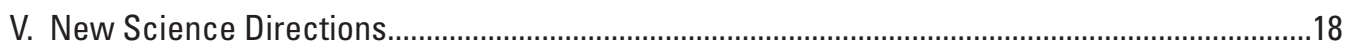

Linking Earth Sciences to Human Health ......................................................................

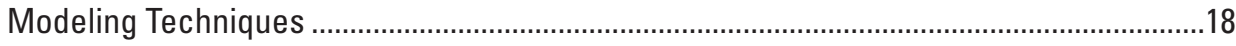

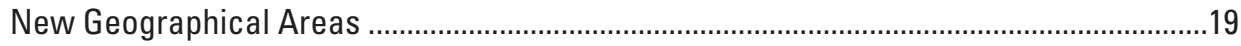

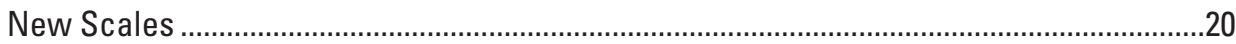

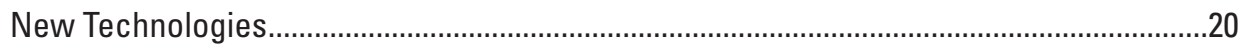

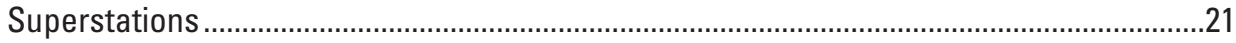

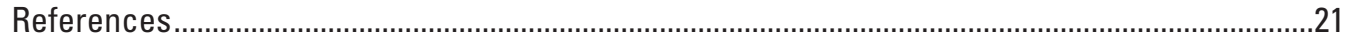

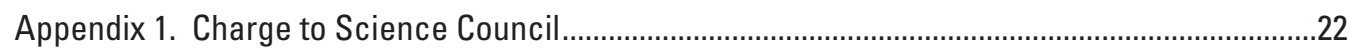

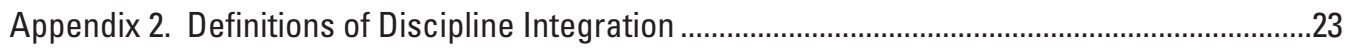

Appendix 3. Fiscal Year 2004 Cooperator List for FISC .................................................................

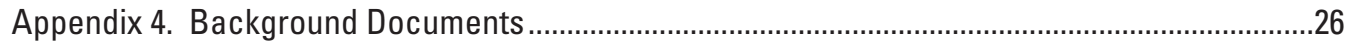

\section{FIGURES}

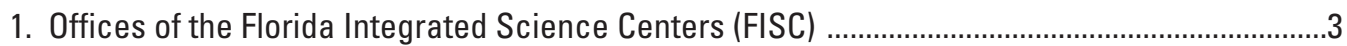

2. World map showing field areas of FISC researchers..............................................................

3. Flow chart of FISC Science Plan ...........................................................................................

4. Distribution of FISC research dollars among the three levels of integration in FY03 ...................5

5. Distribution of FISC FY03 funding by Discipline and level of integration ......................................

6. Example science topics, associated data needs, and integrative activities ...............................10

7. Photograph of green mollusk (Perum viridis) ...........................................................................14

8. Map showing geographic areas designated as priority sites for new science efforts ..............19

\section{TABLE}

1. Intersections between FISC and Eastern Region science priorities 


\title{
Science within the U.S. Geological Survey Florida Integrated Science Center (FISC): Applications, Integration, and New Opportunities
}

\author{
Prepared by the \\ U.S. Geological Survey Florida Integrated Science Center (FISC) Science Council
}

\section{EXECUTIVE SUMMARY}

In recent years, scientists, managers, policymakers, and the general public have grown increasingly aware of the difficulty of understanding and sustainably managing complex environmental systems. One fundamental consideration is "the unity of the environment-the fact that every aspect of the environment is connected to every other in some way ... no branch of environmental science can progress very far without drawing on knowledge from other branches" (National Research Council, 2001). ${ }^{1}$

In 2002, recognizing the need for cross-disciplinary fertilization and integration, the U.S. Geological Survey (USGS) combined three of its research hubs and nine associated field offices in Florida and the Caribbean to form the Florida Integrated Science Center (FISC). Most of the scientists thus incorporated into the FISC administrative structure are affiliated with the Biology, Geology, and Water Disciplines of the USGS. Currently, only two FISC scientists represent the Geography discipline.

This Science Plan was written by the FISC Science Council in response to a request from USGS Eastern Region executives. It provides a first draft of a long-term, strategic science plan for future research by FISC scientists.

The geographic scope of research conducted by FISC scientists is wide-ranging, including projects that are local, regional, national, and global in scale. An informal survey identified FISC field sites on all six continents and a number of Atlantic and Pacific Islands.

The disciplinary scope of FISC research is broad as well. Each USGS Discipline (division) employs scientists with expertise in a wide range of traditional scientific disciplines.

In fiscal year 2003 (FY2003), the FISC Science Council undertook an informal survey of FISC research projects and determined that, in terms of dollars expended, most FISC science ( 54 percent) could be considered discipline-specific, with smaller portions classified as multi-disciplinary (16 percent) or integrated (30 percent).
The Science Council adopted the following FISC long-term science goals:

- Development of reliable and useful decision-making tools for natural-resource management;

- Development of innovative and enhanced inventory and monitoring networks; and

- Provision of cross-discipline data access.

Based on input from FISC scientists, a review of current research activities, and a consideration of significant societal issues encompassed by those activities, the Science Council identified the following FISC core research capabilities:

- Agricultural and urban impacts on ecosystems and water quality and quantity (e.g., adaptive management research);

- Conservation science (e.g., Southeastern mussel surveys; the Manatee Identification Photo System);

- Contaminants, pathogens, and other environmental stressors (e.g., pharmaceuticals, personal-care products, and Cryptosporidium parvum);

- Ecosystem history and climate change (e.g., age and distribution of Florida coral reefs).

- Ecosystem restoration studies (e.g., Tampa Bay; Everglades);

- Effects of invasive species (e.g., Cuban tree frogs; brown anoles; green mussels);

- Interactions among ground water, surface water, and ecosystems (e.g., aquifer storage and recovery studies);

- Natural hazards and associated coastal processes (e.g., coastal erosion; tsunamis); and 


\section{SCIENCE WITHIN THE USGS FISC: APPLICATIONS, INTEGRATION, AND NEW OPPORTUNITIES}

- Water quality and availability (e.g., artificial recharge, stream gaging; flow modeling).

In the future, FISC will apply these core capabilities in the following new directions:

- Capitalization on new technologies (e.g., airborne lidar ranging; streaming resistivity, cross-well borehole tomography);

- Expansion of FISC scientific expertise to research problems in new geographic areas (e.g., Florida panhandle; Puget Sound);

- Linkage of FISC's Earth science investigations with impacts to human health;

- Expansion of special attention to matching temporal and spatial scales of inquiry to the research question at hand (e.g., inter-basin water transfers; rapid-response deployments);
- Usage of the concept of scientific integration to bring appropriate FISC scientists together to answer research questions; and

- Utilization of numerical-modeling techniques to study ecological, hydrological, geological, and land-use change (e.g., integrated coastal models; decisionsupport systems).

For each new science direction, we have identified several priority research areas or topics to provide specific guidance for future research.

${ }^{1}$ National Research Council (2001) Grand Challenges in Environmental Sciences. Washington, DC, National Academy Press. 


\section{INTRODUCTION}

Today's environmental issues and problems have become highly complex, as local and global environmental perspectives are defined by our ability to separate and predict natural versus human-induced change accurately. What historically has been perceived as a simple cause-and-effect relation might today involve a much more detailed ecosystem-wide response that incorporates trophic structures, hydrology, sedimentology and land-use change. Such complex issues require that the USGS scientific disciplines work closely together in developing and implementing a sound science strategy that can reliably provide results and interpretations that are useful, not only to the scientific community, but also to resource and conservation managers.

The demise of some of our Nation's coral reef ecosystems is an example of how integrated science must be used to address the various real and perceived threats to ecosystems. Not only are reefs susceptible to muddy river water that is discharged to the ocean from urban and agricultural run-off (both in terms of light limitation as well as a transport vector for sediment-hosted contaminants), but airborne microorganisms, temperature anomalies (i.e., power-plant effluents), invasive species, water quality, ground-water discharge, storms, and human activities, all deleteriously affect a healthy coral reef ecosystem, either singularly or synergistically.
The USGS Florida Integrated Science Center (FISC) is strategically poised to address these new dimensions in science by integrating expertise from the four USGS Disciplines: Biology, Geography, Geology, and Water. The FISC, created in November 2002, consists of three research hubs: the Center for Aquatic Resource Studies (Gainesville), the Center for Coastal and Watershed Studies (St. Petersburg), and the Center for Water and Restoration Studies (Miami). The three hubs and nine associated field offices (fig. 1) house science teams that conduct original research, environmental assessments, and long-term data collection and monitoring.

An ecosystem consists of a dynamic set of living organisms (plants, animals, and microorganisms) all interacting among themselves and with the environment in which they live (soil, climate, water, and light). An ecosystem does not have precise boundaries -- it can be as small as a pond or a dead tree, or as large as the Earth itself. An ecosystem can also be defined in terms of its vegetation, animal species, or type of relief. FISC scientists conduct research in many ecosystems including coral reefs, the Everglades, offshore habitats, streams, rivers, urban and agricultural systems, and many others.

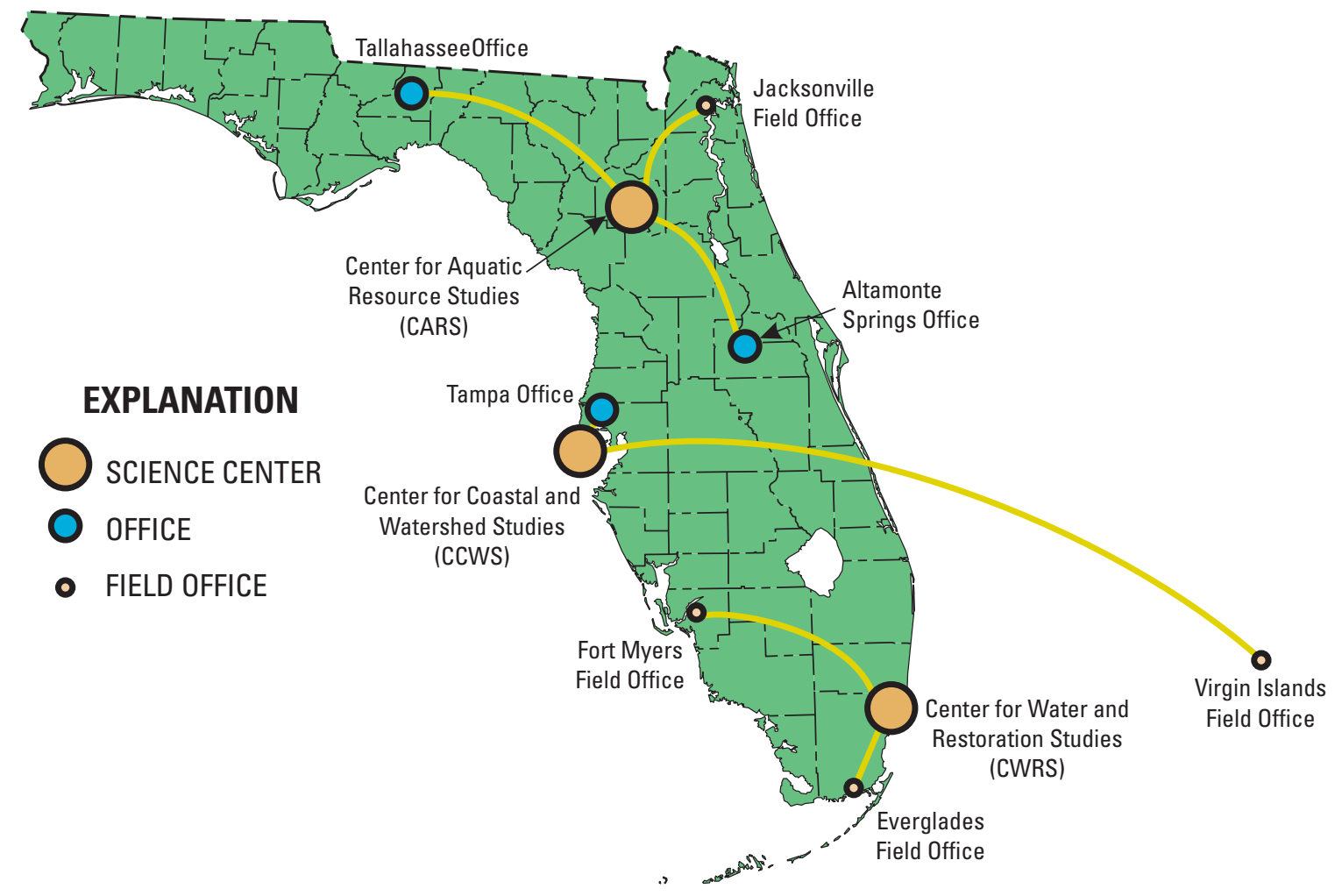

Figure 1. Offices of the Florida Integrated Science Centers. 


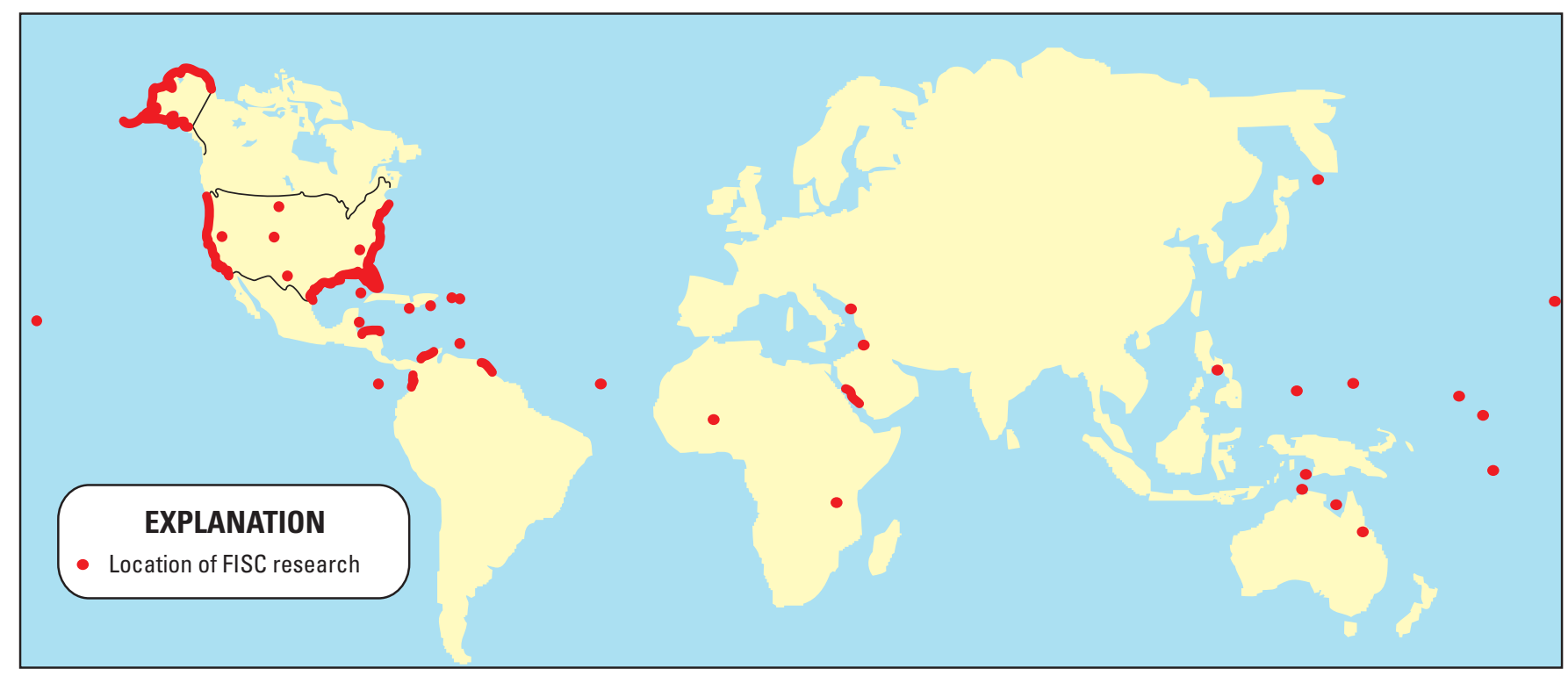

Figure 2. World map showing field areas of FISC research.

The geographic scope of work conducted by FISC scientists is wide-ranging, including projects that are local, regional, national, and global in scale (fig. 2). Examples of some of these projects are highlighted throughout this text. Although FISC facilities are physically located in Florida and the U.S. Caribbean, no geographic limitations in research scope exist. Natural or environmental boundaries that may define the scope of a research problem rarely coincide with political boundaries, and USGS scientists serve the Nation as a whole.

The broad scope of FISC promotes disciplinary diversity as a strength of FISC science. Nevertheless, differences in scientific aims and roles, cultures, traditions, organizational arrangements, operational practices, and partnering arrangements sometimes present difficulties that must be negotiated.

This document provides a first draft of a long-term, strategic science plan for FISC (fig. 3). The next section provides an overview of science integration in FISC, with an informal survey of the distribution of projects among disciplinespecific, multidisciplinary, and integrated-research categories. Subsequent sections discuss FISC science and new opportunities. Appendixes offer ancillary background documents.

\section{DISCIPLINE-SPECIFIC, MULTIDISCIPLINARY, AND INTEGRATED SCIENCE IN FISC}

The Science Council undertook an informal survey in FY2003 to determine the extent of integration within and among currently funded FISC research projects. The aim was

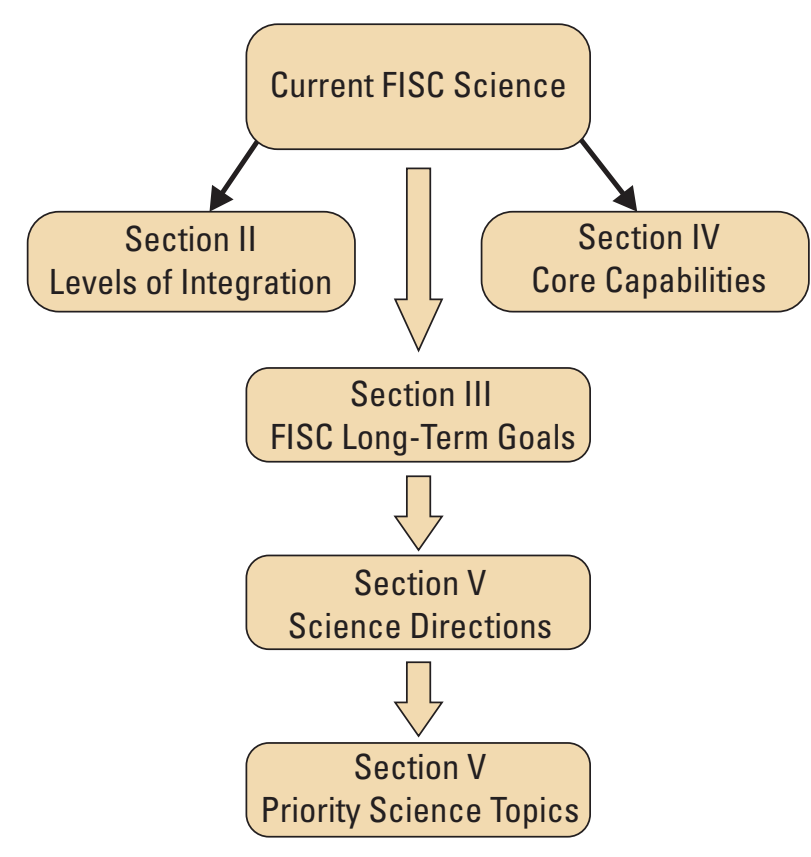

Figure 3. Flow chart of FISC Science Plan.

to gain a general sense of the scope and nature of work being conducted by FISC investigators. The classification scheme included the following three categories:

- Discipline-specific (research carried out by one or more individuals within a single discipline)

- Multidisciplinary (investigators from two or more disciplines work together on a common problem but with limited interaction) 
- Integrated research (the project requires the joint effort of investigators from two or more disciplines)

According to the survey, approximately 54 percent of FY2003 science funding in FISC supported discipline-specific projects, 16 percent supported multidisciplinary projects, and 30 percent supported integrated projects (fig. 4).

Studies within the Water Discipline account for more than 80 percent of the expenditures for discipline-specific science (fig. 5), with the Florida stream-gaging network constituting the primary component. Funding for multidisciplinary science, in contrast, is fairly evenly distributed among the Disciplines. Funding for integrated science is predominately

\section{Science Integration Summary}

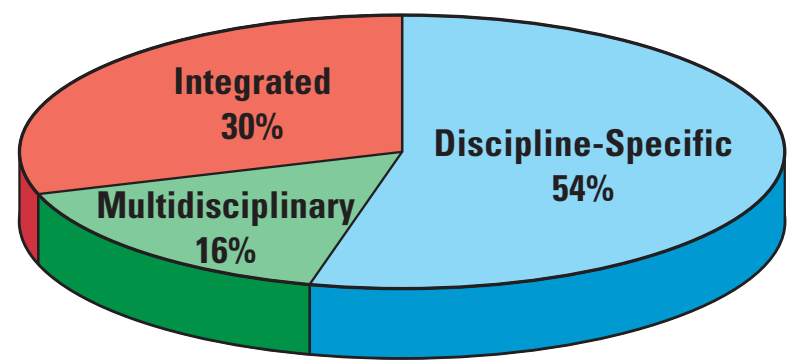

Integrated

Multidisciplinary

Discipline-Specific

Grand Total within the Geology Discipline (more than 65 percent of the total).

Overall, funding for integrated projects comes primarily from federal sources. Notable sources include USGS Surveys, Investigations, and Research Appropriations (SIR) funding (e.g., Coastal and Marine Geology Program), the Place-Based Studies Program (now Priority Ecosystems Science), the Critical Ecosystem Studies Initiative (National Park Service), and reimbursable funds from other federal agencies.

Because the survey was not comprehensive, the results should be interpreted with caution. A number of caveats and explanatory notes are included in Appendix 2.

Figure 4. Distribution of FISC research dollars among the three levels of integration in FY2003. Figures include Surveys, Investigations and Research (SIR) and reimbursable funding.

\section{Funding Breakout by Discipline and Level of Integration}

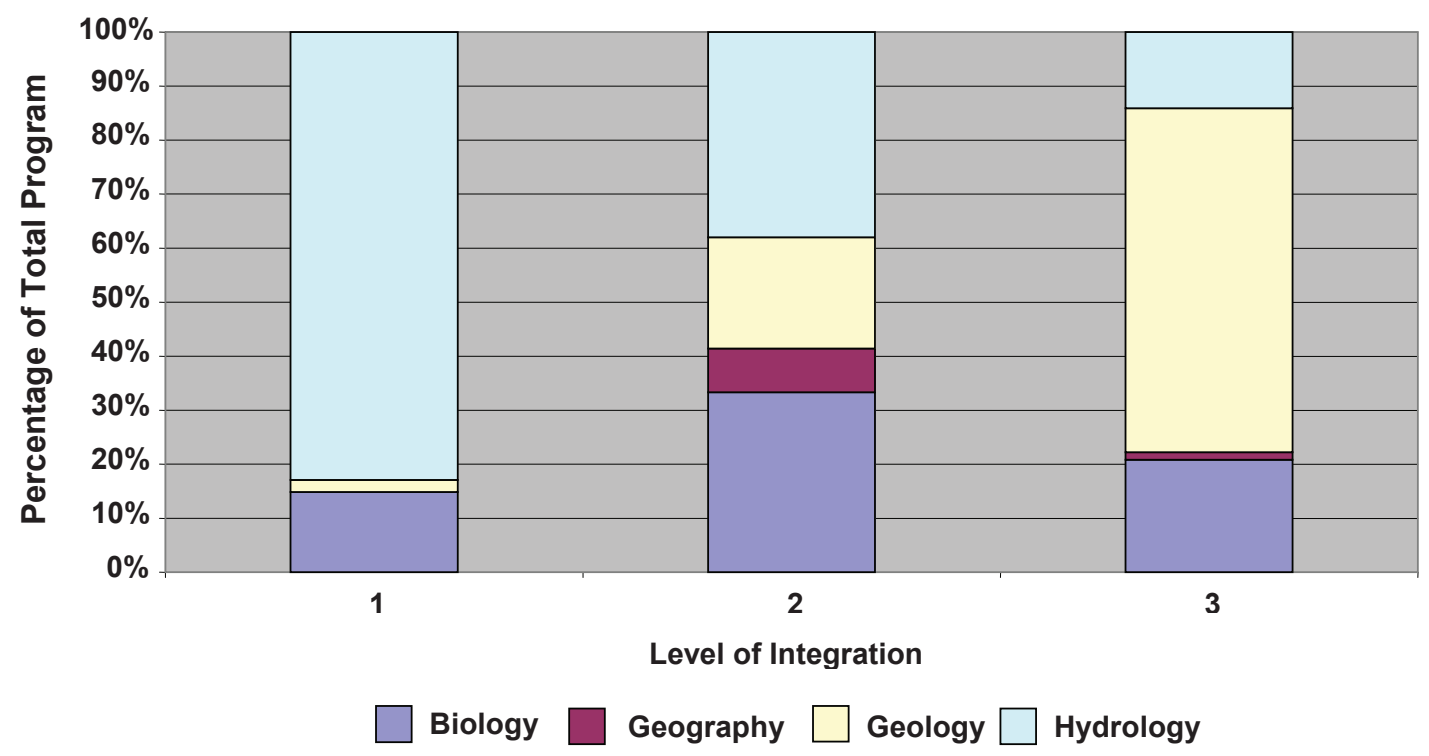

Figure 5. Distribution of FISC FY2003 funding by discipline and level of integration. Includes SIR and reimbursable funding. 


\section{Discipline-specific Studies}

One example of a discipline-specific study is the USGS Florida stream-gaging network, which is part of a national long-term monitoring effort. Water resources data for the 2002 water year include continuous or daily discharge measurements for 392 streams, and measurements of periodic discharge for 15 streams, continuous or daily stage for 191 streams, periodic stage for 13 streams, peak discharge for 33 streams, peak stage for 33 streams, continuous or daily elevations for 14 lakes, and periodic elevations for 49 lakes. Whereas these data are valuable to a wide range of scientists and resource managers, the Water Discipline is responsible for network design, data collection, and curation.

Other discipline-specific examples include studies of fish taxonomy (Biology), assessments of sand resources (Geology), and long-term monitoring of land-surface changes through the Landsat program (Geography).

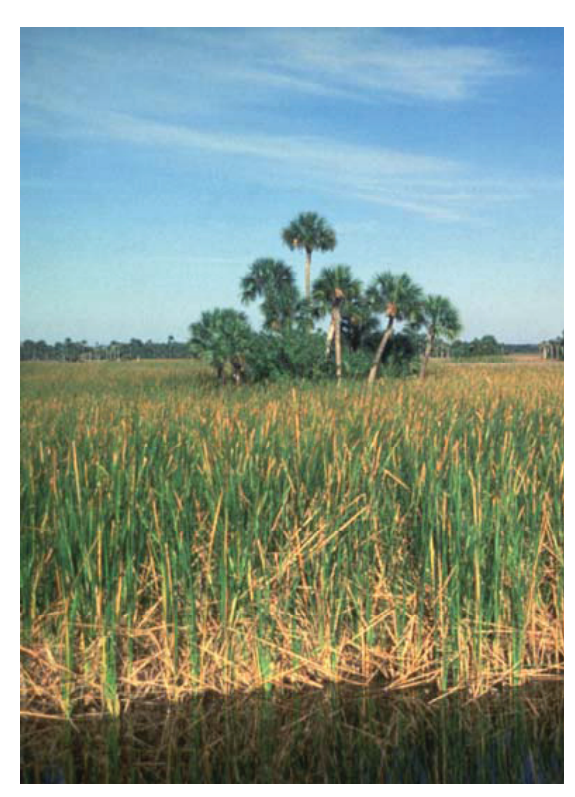

\section{Multidisciplinary Studies}

Examples of multidisciplinary projects include the collaborative work associated with the Southern Inland and Coastal Systems (SICS), Tides and Inflow in the Mangrove Everglades (TIME), and Across Trophic Levels Systems Simulation (ATLSS) modeling efforts (see sofia.usgs.gov). The SICS and TIME models represent flow in the southern Everglades and offshore coastal areas. The ATLSS model suite represents the biologic population dynamics in the Everglades. The SICS/TIME models output water depth and salinity information that is used as input to the ATLSS model. This interaction is multidisciplinary, but, as a one-way data transfer, does not qualify as integrated.

Other examples of multidisciplinary projects include portions of Priority Ecosystem Studies in Florida (Biology, Geography, Geology, Water) and the Coral Reefs Projects (Biology, Geology).

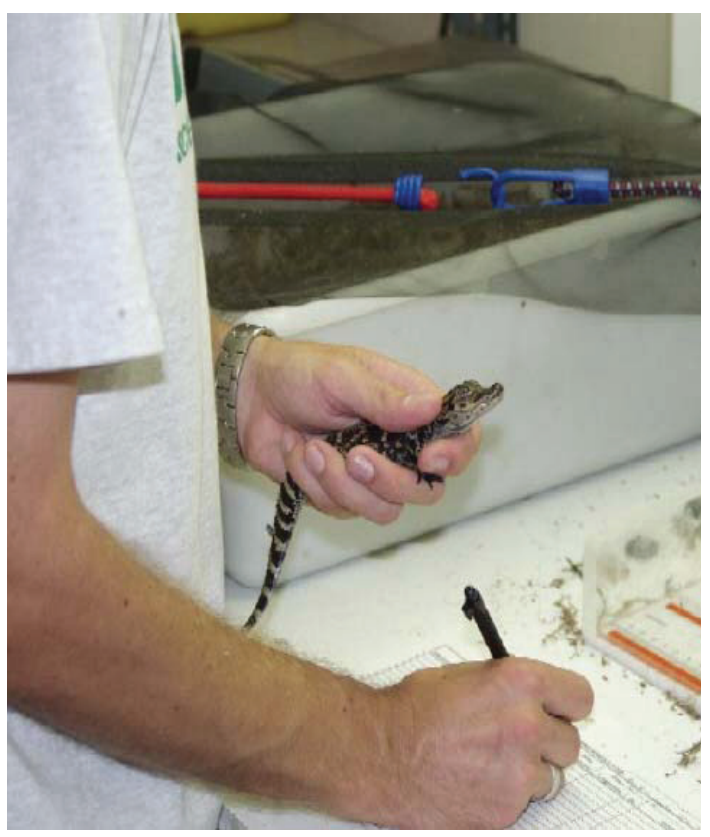




\section{Integrated Science Studies}

The project "Aquatic Cycling of Mercury in the Everglades" is an integrated science study that has been underway for more than seven years in south Florida. Scientists have been using interdisciplinary research to elucidate the processes that lead to toxic or near-toxic levels of mercury in organisms (bioaccumulation) near the top of the food chain and to provide possible linkages to ecosystem-level changes related to the restoration that may make this problem better or worse. To understand this phenomenon adequately, scientists from the USGS Priority Ecosystems Science Initiative, other Federal and State agencies, and academia are using an interdisciplinary approach in which various components of an ecosystem (atmosphere, biota, surface water, ground water, and sediments) are studied contemporaneously (see sofia.usgs.gov).

Large project size is not a requirement for conducting integrated science. Other examples of FY2003 integrated science projects include the Tampa Bay Project (large; Biology, Geography, Geology, Water) and Land Characterization from Remote Sensing (small: Geography, Water, Biology).

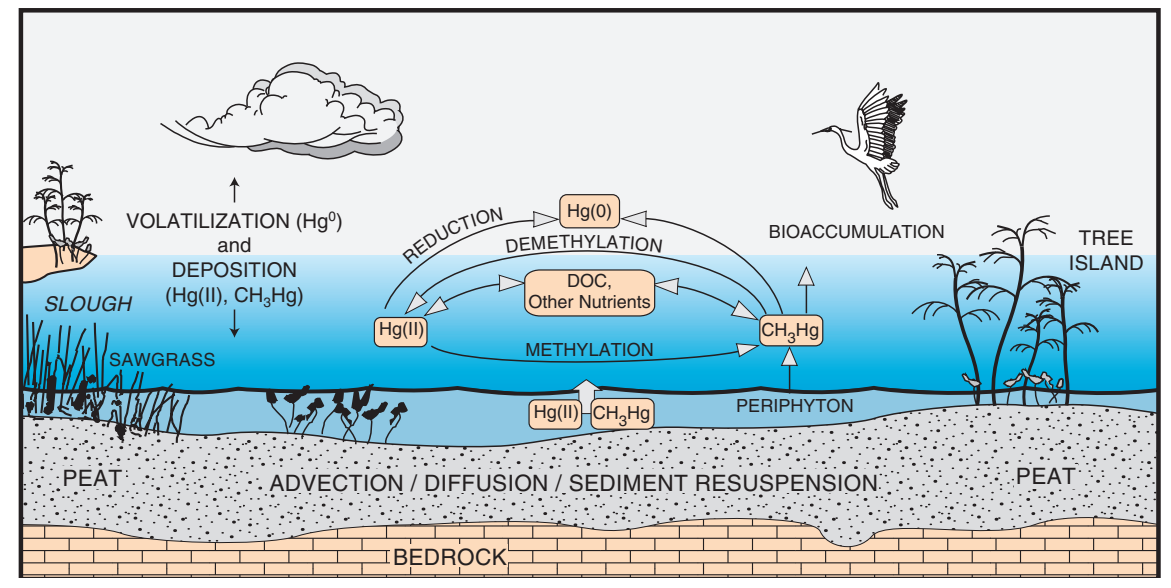

\section{FISC SCIENCE GOALS}

In attempting to answer the question of where FISC science goes in the future, we began with the USGS vision and FISC mission. The Science Council adopted the following goals to guide FISC science into the future. These reflect not only our mission and vision but attempt to reflect our partner and societal needs from FISC science.

- Develop reliable and useful decision-making tools for natural-resource management (e.g., integrated models including social and economic factors; real-time data on the Internet; applications training).

- Develop innovative and enhanced inventory and monitoring networks (i.e., building on long-term databases).

- Provide cross-discipline data access.

\section{USGS Vision}

"The USGS serves the Nation by providing reliable scientific information to

- describe and understand the Earth;

- minimize loss of life and property from natural disasters;

- manage water, biological, energy, and mineral resources; and

- enhance and protect our quality of life."

http://www.usgs.gov/stratplan/vision.html 


\begin{abstract}
USGS Mission
"The mission of the USGS Florida Integrated Science Center is to provide the science needed to support decision-making on natural-resource issues for the people of Florida, the Southeastern States, the
\end{abstract}

U.S. Caribbean, and the Nation."

Florida Integrated Science Center Information Sheet http://fisc.er.usgs.gov/Sci_Flier_P_3-31.pdf

\section{FISC CORE CAPABILITIES AND CONTINUED SCIENCE EXCELLENCE}

Based on input from FISC scientists, a review of current FISC research activities, and significant societal issues encompassed by those activities, the Science Council identified the following FISC research core capabilities. The Science Council attempted to search for areas of research where FISC could lead, excel, and attain the goals outlined above. Although these are current capabilities and science, we anticipate that they should continue as focused areas of research in the near future (5-10 years). Therefore, the core capabilities also can be considered priorities for continued scientific excellence within FISC. FISC has taken the science lead in the topics through long-term and continuing research, partner funding and priorities, and current staff. We feel that whereas new areas of research may open to FISC in the future (see Section V), the following represent our best opportunities to excel in our respective fields without benefit of new avenues of funding or new direction from USGS and our partners. These core capabilities align with USGS national and regional priorities (table 1), our partner priorities (e.g., South Florida Department of Interior (DOI) Science Plan), and our own goals (Section III). We did not rank the capabilities because we felt that they represent our core or the minimum areas in which we must excel to satisfy our mission within USGS and to maintain our visibility and usefulness to our partners. FISC core capabilities are:

- Agricultural and urban impacts on ecosystems and water quality and quantity;

- Conservation science;

- Contaminants, pathogens, and other environmental stressors;

- Ecosystem history and climate change;

- Ecosystem-restoration studies;

- Effects of invasive species;
- Interactions among ground water, surface water, and ecosystems;

- Natural hazards and associated coastal processes; and

- Water quality and availability.

Each capability encompasses not only specific science questions but also associated information needs such as data collection and monitoring. Together, these components address overarching questions that relate to research priorities and their management implications. Figure 6 shows how scientific questions, information, and integration address one of management's Everglades restoration goals, "Getting the Water Quality Right."

\section{Agricultural and Urban Impacts on Water Quantity, Water Quality, and Ecosystems}

The principal human factors affecting ecosystems are population growth, expanding urbanization, and agriculture. In Florida, these factors did not exist a little more than 100 years ago when the State was a wilderness with few inhabitants. Agricultural and urban growth and development have reduced water availability, impaired water quality, and fragmented and altered freshwater, estuarine, and marine ecosystems. Natural habitats have been lost, altered, or exploited to the degree that basic environmental processes have changed. Ecosystem services and functions provided by healthy, productive, and diverse habitats are failing - the functions that normally replenish clean surface water and ground water, keep diseases in check, and sustain native fish and wildlife are threatened.

Science-based approaches that use adaptive resourcemanagement techniques are required to address complex multidisciplinary issues related to urban and agricultural impacts. Environmental assessments, monitoring, hypothesisdriven experiments, and modeling are required to understand better how these impacts affect ecosystems. These multiple approaches are closely linked to restoration activities, such as those currently under way in the Everglades and Tampa Bay. 
Table 1. Intersections between FISC and Eastern Region science priorities $(\mathrm{XX}=$ strong connection, $\mathrm{X}=$ moderate connection, $\mathrm{BLANK}=$ weak or no connection $)$

\begin{tabular}{|c|c|c|c|c|c|c|c|c|c|}
\hline \multicolumn{10}{|c|}{ FISC SCIENCE PLAN } \\
\hline $\begin{array}{l}\text { Eastern Region Science } \\
\text { Priorities }\end{array}$ & 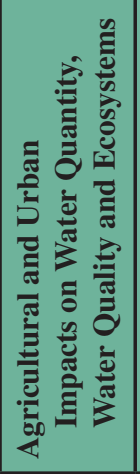 & 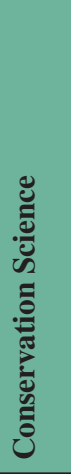 & 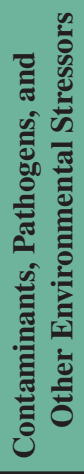 & 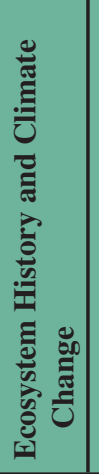 & 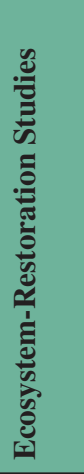 & 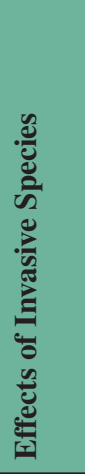 & 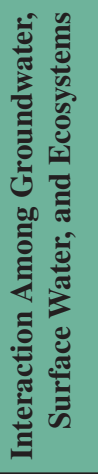 & 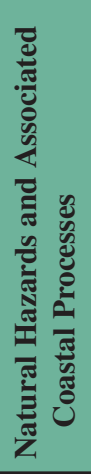 & 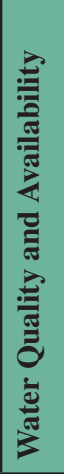 \\
\hline Urban Dynamics & XX & XX & XX & $X$ & XX & & XX & XX & $\mathrm{XX}$ \\
\hline $\begin{array}{l}\text { Ecosystem and Natural } \\
\text { Resources }\end{array}$ & $\mathrm{XX}$ & $\mathrm{x}$ & $\mathrm{XX}$ & $\mathrm{XX}$ & $\mathrm{XX}$ & $\mathrm{XX}$ & $\mathrm{XX}$ & $\mathrm{XX}$ & \\
\hline $\begin{array}{l}\text { Human Health and } \\
\text { Safety }\end{array}$ & $\mathrm{XX}$ & & $\mathrm{XX}$ & $\mathrm{XX}$ & & $\mathrm{XX}$ & $\mathrm{XX}$ & $\mathrm{X}$ & $\mathrm{XX}$ \\
\hline Natural Hazards & $\mathrm{XX}$ & $X$ & XX & XX & $X$ & XX & XX & XX & $\mathrm{XX}$ \\
\hline
\end{tabular}

\section{The Suwannee River Basin:}

\section{A New Opportunity?}

Currently, numerous small-scale USGS and stakeholder research projects are being conducted in the Suwannee River Basin, a mostly pristine area characterized by a high degree of hydrogeologic and ecologic diversity. The nature of the Suwannee River changes dramatically as it flows out of southern Georgia into the Gulf of Mexico: surface-drainage characteristics predominate in the upper two-thirds of the basin, while the southern third reflects the ground-water characteristics of a complicated karst-dominated flow regime. The lower reach, where surface water and ground-water meet, includes numerous large freshwater spring systems with elevated nitrate concentrations. The lower Suwannee River also hosts threatened and endangered species, as well as the world's greatest diversity of subterranean decapod crustaceans (abundances, distributions, and ecological requirements and vulnerabilities still largely unknown). The nature of this watershed and the overlapping study interests of all parties provide an opportunity to link process studies of surface water, ground-water, springs, the estuary system, and unique biota into a holistic science program that would be relevant to stakeholder concerns and consistent with FISC research priorities.
Sample science questions may include:

-What are the impacts of human activities on native plant and animal communities?

-What effects do agricultural and urban activities have on water quantity and quality (e.g., sulfate and its effects on mercury buildup in Everglades biota; nutrient enrichment of the Everglades and coastal waters, including harmful algal blooms)?

-What are the agricultural and urban impacts on coral reefs, seagrass communities, mangroves, and other coastal ecosystems?

- Are pharmaceutical products entering the aquatic environment and affecting biota?

- How do altered hydro-patterns and flows that result from agricultural and urban development affect ecosystems (such as the Everglades)?

- How do agricultural and urban contaminants and nutrients impact fish and wildlife populations? How do land-use and management activities (deep well injection, Aquifer Storage and Recovery (ASR), storm treatment areas) alter biogeochemical processes?

- Have we sufficiently characterized the suite of contaminants in runoff to understand complex combined effects on sensitive ecosystems? 
- How is coastal development (in regions of Florida such as the Big Bend and the southwest coast) likely to impact aquatic communities?

- Is atmospheric deposition a significant pathway for contaminants to enter food webs?

\section{Conservation Science}

The U.S. Fish and Wildlife Service, the National Park Service and other DOI partners are the principal clients of
USGS conservation-related research. While the USGS does not assume advocacy roles, its researchers are frequently asked to investigate patterns and mechanisms of species and faunal decline, identify threats, determine population status and trends, and evaluate changes in range size, conduct surveys, and undertake experimental investigations. Scientists at FISC have contributed to the American Fisheries Society lists of North American imperiled mollusks and fishes, and are presently involved in updating the list of North American imperiled freshwater fishes.

The two leading causes of species decline are habitat loss and impacts of invasive species. Habitat loss will continue as

\section{GET THE WATER QUALITY RIGHT}

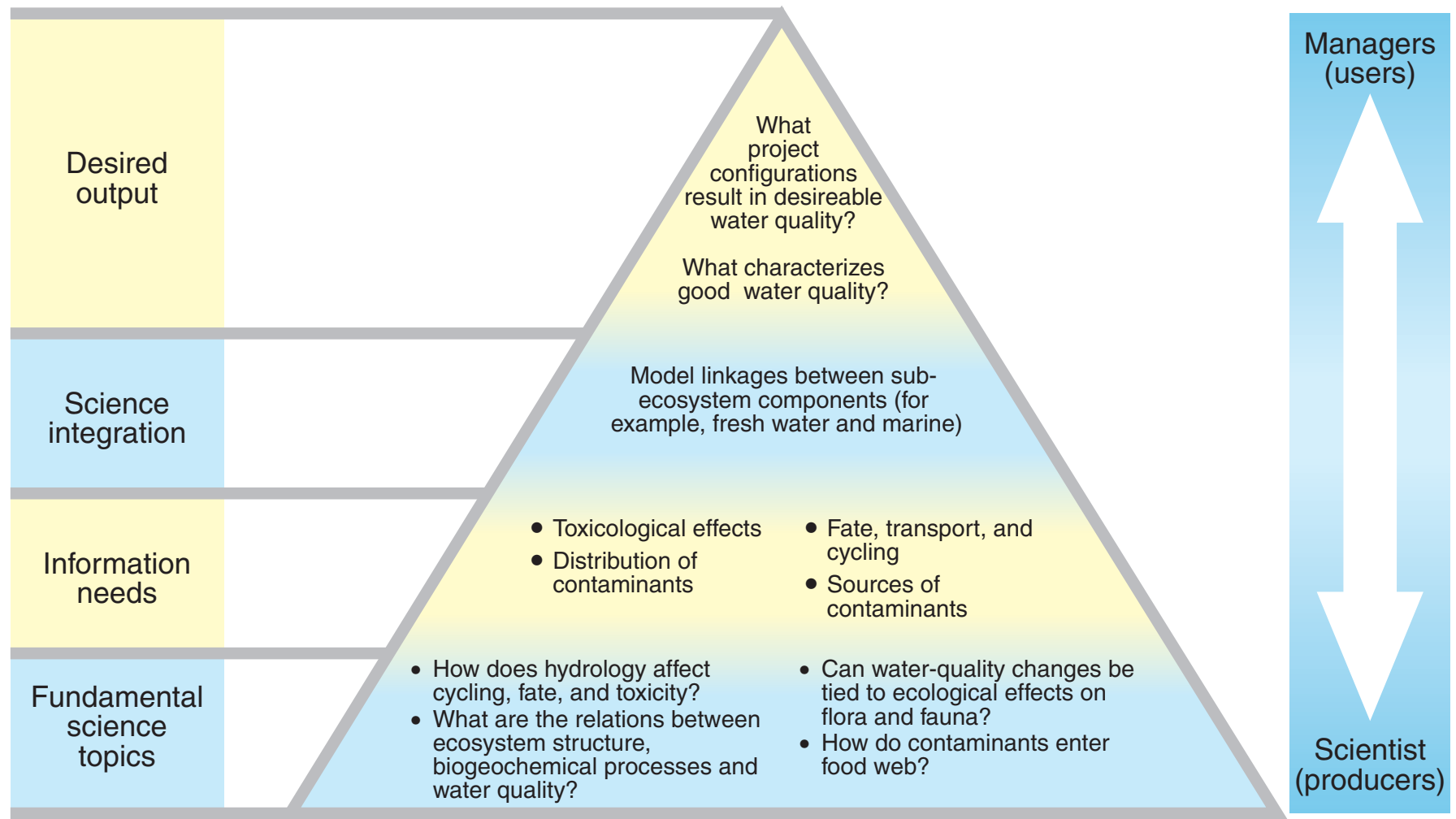

\section{Science Objective 1: Understand ecosystem structure and processes}

Figure 6. Example science topics, associated data needs, and integrative activities. Scientific studies (single-discipline, multidiscipline, and integrated) are undertaken to address priority research questions. Study results, along with other information and data, are synthesized and integrated, often through integrative and predictive models. The models address overarching questions related to research priorities and management. 
the human population increases and more development occurs. Invasive species will be a growing problem as trade with other areas of the world increases in this global economy. As a result, rare species will become an increasing concern.

Conservation is a common theme in many FISC projects, including studies of aquatic macrophytes, invertebrates, amphibians, fishes, birds, and mammals. These investigations encompass multiple scales of biological organization, from genes to ecosystems, and occur over a large geographic area: the southeastern United States, Gulf of Mexico, and the Caribbean. Research topics include biology of imperiled species, experimental, microhabitat, and community ecology, behavior, monitoring, population and faunal trends, and systematics and zoogeography. Recent research emphasis is on trying to understand the mechanisms underlying decline, and the effects of abiotic and biotic factors including interactions with non-indigenous species. Importantly, investigators are evaluating and assembling evidence that southeastern freshwater biota are undergoing escalated decline, local extirpation, and extinction. This ongoing loss threatens the richest temperate aquatic biodiversity in the world.

FISC biologists have compiled life-history attributes of fish in the Appalachian Mountains to look for attributes that rare species have in common. This gives them insight into the causes of a species decline. Seventy percent of the Nation's mussel species are at risk; 95 percent of these occur in the southeast. The Center has conducted exhaustive surveys of southeastern mussel fauna and has been instrumental in supplying information for federal listing of several species. The Manatee Identification Photo System (MIPS) housed at the Center allows researchers to track and monitor individuals manatees.

Sample science questions include:

-What are the causal factors of decline of southeastern fauna?

- Can these be mitigated through management practices?

-What is the historical and current distribution of populations of declining species?

- How can we design statistically valid surveys to document the status of declining populations of endangered species?

\section{Contaminants, Pathogens, and Other Environmental Stressors}

Contaminants, pathogens, and other ecologically influential compounds have been detected in ground-water and surface-water systems throughout the nation and originate from a variety of anthropogenic sources.
For example, the release of treated waste water to surface-water bodies and its land application have led to the release of trace amounts of pharmaceutical and personalcare products (PPCPs) and microbial pathogens into sensitive aquatic systems. Microbes may affect biogeochemical processes in surface water and ground water. Agricultural activities use large amounts of insecticides and herbicides. These compounds undergo degradation to metabolites, which can be more toxic to certain aquatic organisms than their parent compounds. Also, antibiotics and other growth-enhancing compounds are commonly used in animal-feeding operations. Airborne transport of contaminants and pathogens can occur over large distances, as evidenced by mercury from power plants and pathogens from African dust being deposited in Florida. Unprecedented growth and urbanization in many parts of the country have led to the introduction of a variety of contaminants (trace elements, pathogens, organic contaminants) in stormwater runoff that ends up in various waterways, ground water, and coastal waters. To address the numerous ecological and human-health concerns associated with these environmental stressors, FISC scientists must conduct critical, more focused research to determine sources, mode of transport, transformation processes, and the fate of these compounds.

Sample science questions may include:

-What are the sources, cycles, and fate of toxic substances in aquatic ecosystems?

-What are the synergistic effects of multiple contaminants in trace concentrations on various forms of biota in the food chain?

-What trace elements in addition to mercury are occurring in aquatic systems and associated biota from intensive citrus and sugar-cane farming?

- How can we use isotopic and other biochemical indicators to study the uptake of pesticides, their persistent PCPP compounds, and pathogens by biota?

- How do contaminants move and accumulate in the food web?

- How do microbial processes affect ecosystems?

- Are urban and agricultural contaminants affecting coral reefs?

- How do surface water, ground water, and sediment systems influence the persistence, fate, and transport of microbial pathogens in the aquatic ecosystem?

-What are the long-term effects of wastewater discharges (e.g., pharmaceuticals and endocrine disrupters) on natural systems? 


\section{Coral Reefs}

Coral reefs are in decline as a result of both natural forces and human activities. In order to counter this trend, coral reefs must be understood and managed in the context of the greater multidimensional ecosystem, extending from upland areas to the reef and beyond (ridge-to-reef concept). Atmospheric and oceanic circulation and river flow act as transporters in this system, governing the physical, chemical, and biological environment. Many processes harmful to reefs extend well beyond reef areas, and beyond institutional or political boundaries. Cause-and-effect relations are poorly understood for many large-scale processes such as coastal nitrification, increasing atmospheric $\mathrm{CO}_{2}$, contaminant transport, and widespread coral disease. The basic processes at work need to be understood on scales ranging from molecular to global. Because coral reefs are dynamic bio-geological structures, it is important to have a temporal, pre-historical view of their development to understand human impacts better. FISC scientists conduct integrated laboratory and field research (including experiments, long-term data collection, monitoring, analysis, and predictive modeling) to understand the processes at work in coral reef systems and to determine how those processes are affected by human activities.

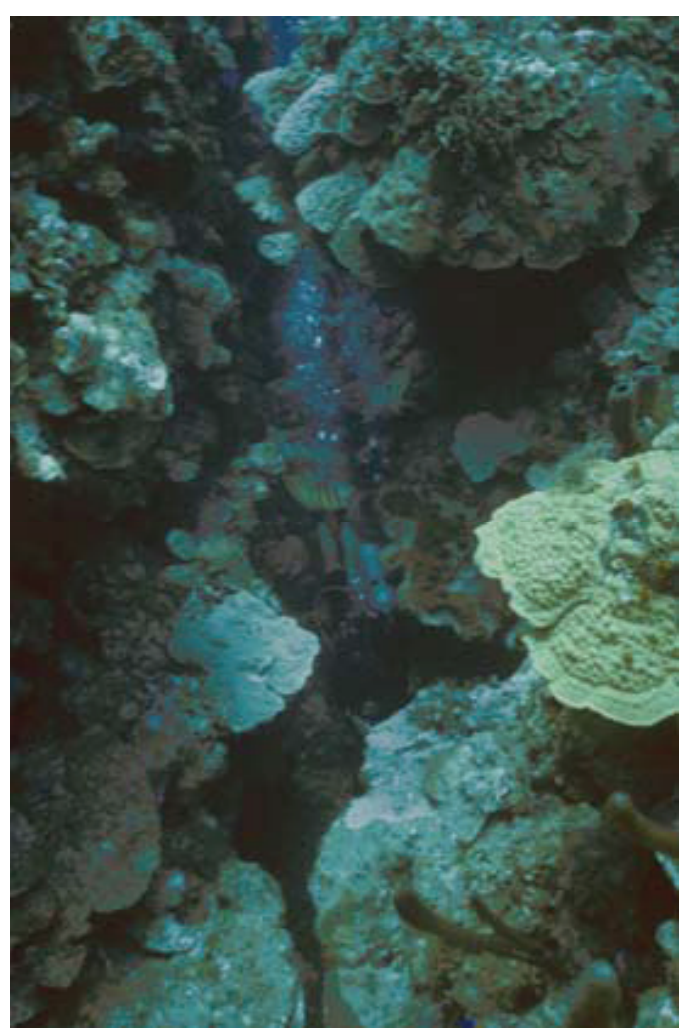

\section{Ecosystem History and Climate Change}

FISC scientists are working throughout the southeastern United States, in Chesapeake Bay, Puget Sound, the Rocky Mountains, Great Plains, and elsewhere to reconstruct the history of changing ecosystems. Florida is the focus of intense application of several integrated geological disciplines that together provide an understanding of natural versus humaninduced change in the greater Everglades ecosystem. Two overlapping, but distinct, categories of issues are addressed by FISC scientists: 1) studies of climate change interpret how climate has evolved in the past and how ecosystems have responded to those changes; and 2) studies of ecosystem history distinguish human impacts from natural change, often on time scales much shorter than the effects of climate change. Both these activities involve the complete integration of sedimentology, geochemistry, ecology, and paleontology and their related sub-disciplines and benefit from related research in the geography.

Ecosystem history has played a triple role in Everglades restoration. Through studies of sediment cores and aerial photographs, USGS scientists have determined: 1) how and when contaminants have entered the Everglades system; 2) how coastal salinity has varied in response to onshore water-management practices; and 3) natural-system targets for restoration.
Florida has been a natural laboratory for documenting important aspects of global climate change. Studies of the age and distribution of Florida coral reefs have been used to establish past sea levels and the interaction between sea level and climate.

On time scales of 10,000 to several hundred thousand years, reefs have grown along Florida's margins, been abandoned by a lowering sea, and grown again as sea level returned to the current level. Significantly, the presence of elkhorn corals within fossil reefs has allowed dating of past sea level to within + or - 5 meters. On much shorter time scales, annually banded coral skeletons in Florida reefs have provided proxy records with sub-annual resolution for temperature and salinity during the past 5,000 years.

Ecosystem history and climate change will continue to be priorities for FISC because of the continuing need to understand the past and predict future environments. The same goal is fundamental to all four of the Eastern Region's integrated science priorities. Careful dating of fossils and sediments, analyses of fossil assemblages, understanding of the ecological requirements of the fossil organisms when they were alive and what they can tell us about past environment will be an ongoing effort central to FISC science for the foreseeable future. 
Sample science questions may include:

-What was the Everglades ecosystem like in 1850 ?

- How has the nutrient history of Chesapeake Bay changed since settlement by Europeans?

- The change in land use and cover in Florida parallels those changes that have been observed globally. What can we learn through the comparative analyses of these changes?

-What were the dominant plant species and communities before human impacts to the environment?

- Are present-day ecosystem perturbations similar to those that have occurred in the past and how has the system responded to past perturbations?

- How have coral reefs changed in the past and how might they respond to predicted climate change?

- How has the geologic record recorded hypoxic and anoxic events? What are the processes that induce these events? What is the relation between climate change and these events?

\section{Ecosystem-Restoration Studies}

Ecosystems worldwide have been impacted by deforestation, climate change, introduction of exotic species, hydrologic manipulations, and a myriad of other human activities. These impacts have led to impairment of ecological structure and function. Restoration studies seek to delineate the extent of damage to the ecosystem, define the functions and linkages among organisms and their physical environment, investigate possible approaches to restoring natural functions, provide tools for evaluating restoration alternatives, and develop monitoring protocols to evaluate restoration success.

Currently, FISC scientists are engaged in ecosystemrestoration research in a wide variety of environments, including south Florida, Tampa Bay, Puget Sound, and Chesapeake Bay. Such efforts include the provision of comprehensive regional-scale monitoring information, quality-controlled and assured databases and internet access systems, ecological and hydrologic models that include hydrology, biology, geology, geography, and other land characteristics, research on artificial recharge (such as ASR activities), estuarine and coastal studies, geochemical studies, studies of threatened/endangered species, and information concerning ecosystem history.

Sample science questions may include:

- How do you restore an ecosystem? To what environmental conditions do you restore it?

- How do you know when restoration is successful?

-What ecosystem shifts can be expected during and after restoration?

\section{Tampa Bay}

Tampa Bay, one of the Gulf of Mexico's largest estuaries, provides examples of the environmental stresses that our Nation's bays and estuaries typically face. More than 2 million people live in the Tampa Bay watershed, and the population continues to grow. Increased development demands more fresh water, generates more waste products, and results in continued anthropogenic alterations in the bay and along its shores. Successful management of coastal resources requires an understanding of how natural and anthropogenic changes have affected coastal ecosystems in the past and how these changes will likely affect coastal resources in the future. The USGS Tampa Bay Study is examining anthropogenic and natural ecosystem change by investigating the interrelated geological, biological, chemical, and hydrological components of the estuarine system. USGS scientists from each Discipline are working with Federal, State, and local partners to develop and implement an integrated science strategy for estuarine research.

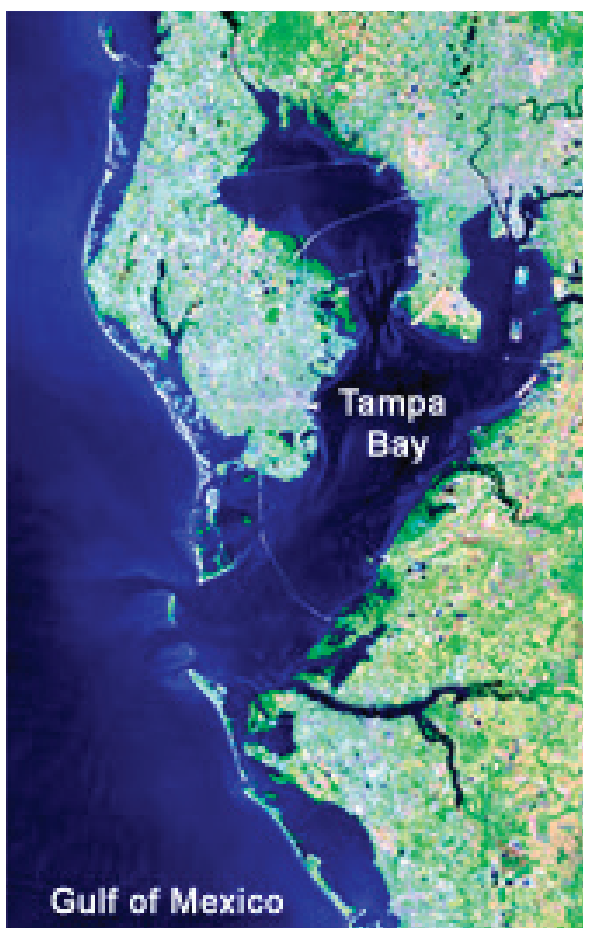


- What geochemical and microbiological changes occur as surface water is stored in aquifer systems and is later withdrawn for augmenting ecosystem needs?

\section{Effects of Invasive Species}

Throughout the world, invasive species ranging in size from microscopic organisms to large mammals threaten natural habitats, native species, and even humans. The impacts of invasive species have recently been compounded by natural and anthropogenic factors such as: 1) climate change;

2) land-use change; and 3) our own accelerated transportation of goods and services around the world. The health of endemic plants, fish, and birds may have become compromised by a suite of invasive species including pathogenic bacteria, fungi, viruses, protozoa, and toxic algae. In Florida, both coastal and upland habitats are currently being altered by the rapid proliferation of invasive species. The rate of successful invasions is likely enhanced by abiotic ecosystem stressors such as anomalous temperature fluctuations, and changes in water/sediment quality and availability. Some endemic fauna and flora have been displaced by invasive species, often altering fundamental ecological structures and functions.

For example, many fish species such as the Asian swamp eel are invading habitats in the Everglades. Their effects on native species and the ecosystem are still unknown. The inadvertent importation of Cuban treefrogs (Osteopilus septentrionalis) on ornamental plants has resulted in their competition with native frog species. Introduced brown anoles (Anolis sagrei) are replacing native Carolina anoles (Anolis caroliniana) in many areas of the state. Old World Climbing Fern (Lygodium microphyllum) has overtaken many tree islands in Loxahatchee National Wildlife Refuge and can change the fire regime by sending fire into the canopy. West Nile Virus has now been confirmed in native alligator (Alligator mississippiensis) populations and apparently causes a high rate of mortality. Green mussels (Perna viridis) have been introduced via ballast water into Tampa Bay (fig. 7).
Within FISC, scientists are addressing several aspects of the invasive-species problem. Scientists conduct both field and laboratory research on invasive species to assess the impacts on native biota and the potential for spread. FISC scientists also maintain the Nonindigenous Aquatic Species (NAS) Database, which tracks introductions and their status nationwide. Using information gathered from these different approaches, biologists conduct risk assessments. The NAS database is also used in trend analysis and offers insight into sources, pathways, and hot spots for introductions - information that can be used to prevent future introductions.

Sample science questions may include:

- Can we predict and prevent the proliferation of new invasive species?

- Can we control existing populations of invasive species?

- Can we develop an assessment of invasive species populations and risk?

- What is the ecological and economic impact of invasive species?

- Where did invasive species come from (based on genetics)?

- What are the likely sources and pathways of new invasions?

\section{Interaction among Ground water, Surface Water, and Ecosystems}

The unique characteristics of the surface-water and ground-water systems in areas such as Florida necessitate that their interactions be considered. Exchange between the surface-water and ground-water systems is facilitated by the highly conductive nature of the limestone and karst aquifers. The low surface gradients compound the effect; surface-

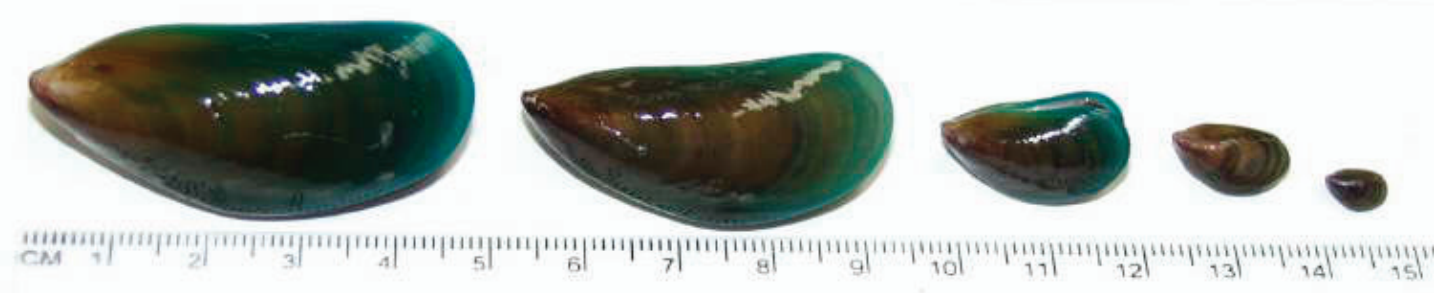

Figure 7. Green mollusk (Perum viridis). 


\section{Greater Everglades Ecosystem Restoration Priority Ecosystems Studies (formerly Place-Based Studies)}

The Greater Everglades Ecosystem Restoration effort, part of the Priority Ecosystems Studies, is closely linked to the larger Federal and State funded Everglades restoration efforts. This program encompasses data collection, ecological and hydrologic modeling, information integration and synthesis, plus the development of tools to make scientific information readily available to Federal and State agencies and the general public. USGS provides regional-scale monitoring, databases and Internet access systems, ecological and hydrologic models and research on aquifer storage and recovery, estuarine and bay processes, biogeochemical cycling, and ecosystem history. The programmatic emphasis on synthesis supports integration of the accumulated scientific understanding, helps to chart future scientific directions, and contributes to interagency synthesis activities (e.g., http://sofia.usgs.gov). Integration of such projects can be encouraged by increasing interaction among principal investigators, incorporating additional interactive feedback and linkages within modeling efforts, and increasing funding opportunities specifically for integrated work.

- Increase interaction among principal investigators-e.g., by conducting more annual meetings of principal investigators and conferences like GEER, and forming teams around central PBS questions.

- Incorporate additional interactive feedback and linkages within the SICS/TIME, ATLSS, and other Everglades models by facilitating interaction among the ecological, geographic, and hydrologic investigators.

- Increase funding opportunities specifically for integrated work such as the Land Characteristics from Remote Sensing Project that links hydrologists, geographers, and biologists and enhances opportunities for integrative interaction.

water fluxes are relatively low and ground-water exchange is relatively high. The issues of surface-water habitat response to ground-water pumpage, and ground-water-recharge response to surface-water management changes, are significant. The potential for aquifer storage and recovery (artificial recharge), the potential for saltwater intrusion, the effect of urban and agricultural development, and changes in plant and aquatic animal communities are all interconnected.

Research has approached this problem of surface-water and ground-water interactions in a two-fold fashion. Field process studies define parameters and gather information crucial to an understanding of the interactions. Numerical models are used to simulate and view the interactions. Together, these approaches have advanced our understanding of rivers, aquifers, and wetlands (such as the Everglades).

Research interests include ecosystem restoration, ASR, aquifer confinement and leakage, time-of-travel studies, fresh ground-water and surface-water inflows to estuaries, water use, and water-management

strategies.

Hydrologic and biologic interests overlap, and the coupling of research and modeling efforts must continue to be a priority. Projects that specifically involve one system, either surface water or ground water, must implicitly account for the effects of the other. The ecologic studies depend on the finding of the hydrologic studies, and vice versa. Florida is located on layers of carbonate rocks that have undergone millions of years of karstification. In the past few decades, humans have started injecting waste water into the underlying karst rocks as a way of disposing of contaminants. The fate and transport of injected waste water are not known. Therefore, obvious and significant questions for the public and for water and ecosystem-resource mangers are: How deep does the injectant go, and can scientists adequately model its flow and dispersal in Florida? The concern is that injected water could contaminate both onshore and offshore environments and could become a health threats to humans in coastal areas.

Sample science questions may include:

- How are plant-community structure and fitness affected by hydrologic perturbations?

-What is the nature of hydrogeological inter-connection between the surficial and Floridan aquifer systems?

-What is the capacity of the Floridan aquifer as a sustainable long-term water source?

-What is the fate of injected waste water?

- Do karst aquifers provide suitable attenuation and filtration processes that impede movement of solute and microbial contaminants?

- What are the effects of mining on water and environmental resources? 


\section{Natural Hazards and Associated Coastal Processes}

Most population centers in the United States are located within the coastal zone where the population and density of economic development are expected to increase substantially in the foreseeable future. These trends have important implications with regard to the present and future impacts of coastal hazards on the infrastructure and environment and the associated impacts of growth and development on coastal ecosystems. A priority issue for the USGS Water Cooperative Program is associated with hydrologic hazards and includes monitoring the occurrence and magnitude of extreme events such as floods and droughts.

The common coastal hazards are storm waves and inundation, beach and bluff erosion, earth movement (landslides, subsidence, faulting), tsunami waves and inundation, and a relative rise in sea level. Some of the most socially relevant activities that the USGS conducts are analyses of natural hazards and the distribution of products that describe the hazard vulnerability of an area. For coastal hazards this requires: (1) utilizing advanced technologies such as lidar surveys and GIS mapping of coastal morphology and historical changes and hazard impacts; (2) understanding the anticipated changes associated with both short-term environmental events (hurricanes and other storms, droughts, tsunamis, landslides, harmful algal blooms) and long-term processes (subsidence, sea-level rise); and (3) generating national assessments and vulnerability analyses for multiple hazards. Because storms frequently impact nearly all coasts, a more advanced goal of the coastal-hazard research is real-time forecasting of storm impacts as a major storm is approaching a coast.

Anticipating how human alterations will affect coastal processes and ecosystems represents a formidable challenge. Human activities, such as emplacement of coastal structures on the beach, have induced or exacerbated the beacherosion hazard by impounding sand and causing or accelerating erosion down-drift of the structure. Along some high-relief coasts, watering lawns, which increases soil saturation, has facilitated sea-cliff failure. In the Gulf Coast region, subsidence (inundation) and faulting hazards have been accelerated or induced by subsurface withdrawal of fluids, including ground water and oil and gas. The subsidence and faulting have led to widespread wetland loss in some areas, such as the Mississippi River delta plain, and may contribute to formation of sinkholes in Florida. Additional concerns include the impacts of residential and industrial development on ecosystems such as degradation or loss of wetlands and sea grasses. Ecosystem alteration continues to be a major issue where wetlands or coastal water bodies are drained or filled for construction sites and agricultural uses or untreated urban or industrial waters are discharged into bays or estuaries.
Sample science questions may include:

-What are the long-term impacts of sea-level rise? How will it impact shallow-aquifer water supply?

- How does the nearshore geologic framework influence coastal change?

-Where are beaches eroding, and what can be done to mitigate erosion?

- Can we predict the formation of sinkholes?

- How do we predict and control the impacts of inshore flooding?

- How can we reduce the impacts of coastal storms (wind, storm surge, and flooding) on human life and property?

- How can we minimize effects of coastal development on ecosystems?

-What are the short- and long-term impacts of droughts on saltwater intrusion?

-Where are beaches accreting? What causes them to grow?

\section{Water Quality and Availability}

The USGS is positioned to provide unbiased information about the vulnerability of water-supply sources, the availability of water for human consumption and for the natural environment, the quality of ground water and surface water, flood and drought mitigation, and trend analyses based on historical databases. USGS provides information on stream flow that is used for flood warnings, water-supply development and management, State-wide flow and water-quality standards (minimum flows and levels), and research on surface-water/groundwater interactions, evapotranspiration, flow modeling, and other scientific studies. Recent work by USGS scientists using suspended-sediment surrogates for evaluating phosphorus and other nutrient load calculations provides new approaches to evaluate and quantify total maximum daily loads (TMDLs) via optical and acoustic technologies.

Sample science questions include:

- How does the hydrogeologic framework affect water availability and quality?

- What are the current and long-term trends for "mining" of ground water?

- Is our ground water supply sustainable? 
- What impact has climate change had on availability and distribution of water resources?

- Can existing optical and acoustic technologies assist with the quantification of TMDL from both point and non-point sources?

- How can the quantity and quality of our drinking water be protected best?

- Will utilization of alternative water sources have adverse environmental consequences (e.g., coastal desalination)?

- How will altered conveyance systems and water deliveries affect the hydrology of natural areas?

- Do municipal supply and disposal practices have a practical limit in terms of water quantity, water quality, well-field spacing, and economics?

\section{Florida's Hydrologic Surveillance Program}

Florida's Hydrologic Surveillance Program administers an extensive hydrologic monitoring network in Florida and monitors the quality and quantity of water in Florida's rivers and aquifers. Through the Federal-State Cooperative Water Program, Florida's Surveillance Program plays an active role in water-related geologic, biologic, land-use, water-use, and mapping studies in many parts of the State by providing reliable, timely, and impartial information needed to understand and wisely manage the water resources that contribute to the safety, health, and well-being of Florida's citizens. The Surveillance Program provides scientific data at more than 2,000 sites in Florida and provides provisional data through real-time satellite, telephone, or radio telemetry at more than 500 data sites. These data are archived in the National Water Information System (NWIS) database. These data-collection programs advance science activities in Florida and the U.S. in many ways including: investigating new approaches to measuring continuous water velocity, water level, and water flow in complex water bodies, such as tidally affected streams and springs; understanding the interaction between saline and fresh water in Florida's rivers, and coastal and estuarine waters; understanding the interaction of lakes and wetlands with ground water; developing techniques for monitoring sinkhole-prone areas for early detection of sinkhole formation; understanding watershed processes that affect ecological systems; and investigating the impacts on the natural systems caused by water withdrawals. Additionally, analyses of these data using scientifically sound principles and statistics allow water managers and forecasters in the State to make informed, timely decisions with regard to hydrologic hazards and the prediction of flood flows, storm surges, and water levels for the public. Additional purposes include flood- and drought-alert networks, reservoir management, and determining municipal, agricultural, and industrial water supply, and minimumflow requirements.

Finally, long-term hydrologic data collected by Florida's Hydrologic Surveillance Program form the basis for many scientific studies related to the quantity and quality of surface-water, ground water, and atmospheric deposition; simulation of the hydrologic-flow systems; predicting future supplies; evaluating the response of hydrologic systems to induced stresses; and defining potential problems early enough to allow for proper planning and management, as well as quantifying rainfall, evapotranspiration, recharge processes, and nutrient cycling. 


\section{NEW SCIENCE DIRECTIONS}

Our challenge in the future as funding priorities change or new funding is found is to take the core capabilities present in FISC (see Section IV) and apply them in new directions. We do not anticipate wholesale changes in FISC science staff or additional funding to open entire new fields of research in which we can excel. Rather, we anticipate using the current and capable scientists in FISC and key additions of replacement science staff through attrition to apply their collective knowledge in new directions developed within USGS and in cooperation with our partners. This section outlines several new directions for FISC science identified during a series of discussions among FISC scientists. Under each new direction, we have identified several priority topics or areas for new research.

\section{Linking Earth Sciences to Human Health}

Serious human-health concerns have arisen in recent years, such as those related to emerging infectious diseases, ground-water and surface-water contamination, and tracemetal poisoning. Many of these health concerns relate directly to earth processes and the environment. For example, the widespread use of agricultural chemicals (fertilizers, pesticides, antibiotics, and other animal growth enhancers) and PPCPs have introduced compounds to aquatic systems in trace amounts that have the potential to cause disruption of hormone systems. Long-range transport of industrial emissions that contain trace elements and aromatic hydrocarbons also has the potential to cause serious impacts on human health. Wastedisposal activities (including the land application of reclaimed water and treated sewage effluent) have introduced pathogens that can aid in the spread of human disease. Changing climate alters habitat and may make the spread of insect-borne diseases such as West Nile Virus more prevalent.

USGS researchers have developed powerful new tools and techniques to conduct Earth-science studies that will help us understand the environmental contributions to diseases and human health better. Hydrological, biogeochemical, and ecological studies can lead to an improved understanding of the key factors that control the spatial and temporal distribution of disease risk and effects of natural and manmade contaminants on human health. As a way of addressing several humanhealth issues, the USGS has forged partnerships with various groups (U.S. Environmental Protection Agency (EPA), universities, and public-health agencies) to study links between environmental factors and human health. Some important examples of these cooperative studies include: 1) the geographic distribution of West Nile virus; 2) the occurrence and distribution of low levels of pesticides (and their degradates) and pharmaceutical compounds in surface water and ground water; 3 ) factors contributing to clusters of elevated breast and bladder cancers, and childhood leukemia cases in localized areas; and 4) the distribution of pathogens, trace metals, pesti- cides, and radioactive isotopes in African dust that may cause respiratory distress. Determining the etiology of these diseases is helping public-health officials to determine how to mitigate these hazards.

FISC scientists have identified the following topics as priorities for future studies that link Earth-science information to human health:

- Endocrine-disruption compounds in surface-water and ground-water systems used for drinking water (e.g., herbicides and their degradates in surface water and ground-water systems, sterols and hormonal compounds in ground water resulting from the land application of treated waste water);

- Long-range transport of hydrocarbons and selected trace elements in industrial emissions (e.g., deposition of polynuclear aromatic hydrocarbons, arsenic, radioactive isotopes, and mercury in south Florida);

- Quantification of microbial pathogen reservoirs in water, agricultural and urban soils, and beach sand (implications of dredging and storm events to mobilize pathogens); and

- Water, airborne, and biological pathogens in urban and rural areas (e.g., the transport of natural and anthropogenic contaminants to public supply wells; viruses, bacteria, and fungi in African dust).

\section{Modeling Techniques (ecological, hydrological, geological, land-use change)}

Numerical modeling techniques have become an essential tool in water-management decision making and risk assessment. For example, the representation of hydrologic and ecologic systems as nearly continuous entities, rather than a sparse collection of point field measurements, requires a spatial modeling approach. In addition, predicting the likely outcome of a given management scheme or natural process requires numerical models that accurately represent the complexity of controlling processes. Numerical models are usually required to represent these processes with sufficient complexity. To date, hydrologic models have been used by FISC scientists to determine water-level, hydro-period, flow, water-quality issues such as salt-water intrusion, and water quantity in major aquifers, river, wetland, and estuary systems. Ecologic models have been applied to determine biotic growth, mortality, migration, and feeding patterns of vertebrates and invertebrates.

Several general types of models are especially important within the context of FISC research: integrated models, riskassessment models, decision-support systems, and adaptivemanagement models. Integrated models numerically attempted to describe the complex interrelations among hydrologic 
(fresh- and saltwater) systems and selected ecologic components (e.g., fish and birds). Risk-assessment models are relevant to studies of flooding, species mortality, contamination of surface-water and ground-water systems, and the utility of modified water-management schemes. The application of stochastically based models to risk assessment in particular represents a potential growth area for FISC research.

As part of a decision-support system, complementary models can be used in the formulation of predictive forecasts. Analysis of the predictive capabilities can then lead to adapting the modeling system for better predictive capabilities. This use of feedback to improve modeling systems has not yet been utilized in any major FISC project and needs to be considered, especially in ecosystem-restoration models and scenario models.

FISC scientists have identified the following modeling studies as priorities for future research efforts:

- Adaptive Management (e.g., sub-lethal chronic stressors on endangered and threatened species and other biota; individual and cumulative risks on aquatic resources from natural and anthropogenic disturbance and resultant change to structure, process, and pattern).

- Decision-Support Systems (e.g., non-point-source contamination in watersheds; surface-water-flow models for habitat-assessment studies, cost/benefit analysis involving public-health impacts from varied land use).

- Geochemical-mixing models (e.g., mixing dynamics associated with injected waters and native groundwater in aquifer-storage/recovery projects; surfacewater entry into aquifer systems; and submarine ground-water discharge).
- Integrated Models (e.g., coastal-zone processes, coral reef and terrestrial ecosystem models that capture carbon and water cycling, nitrate flux, and vegetation structure).

- Microbial risk assessment (e.g., risks to aquatic biota).

- Risk-Assessment Models (e.g., complex exposure patterns involving multiple exposure pathways and multiple contaminants; combining chemical dynamics models with toxicity data to develop ecological risk assessment).

\section{New Geographical Areas}

A growing appreciation for the complexity of environmental issues of societal importance is developing nationwide. The same is true in Florida and other regions where FISC scientists routinely work. The southeastern United States and the Florida/Caribbean in particular, have unique physiographic characteristics that often dictate a strong coupling of the four core Disciplines in the development of any comprehensive science approach. For example, an examination of groundwater/surface-water exchange, or an investigation into flux processes across the land/sea boundary along any Florida coastline, requires a sound understanding of the complex geologic control on hydrology. Similarly, biological microniches are often defined directly by a particular hydrogeologic setting. Such examples illustrate the complex interdependence of core Disciplines in defining a particular ecosystem and also illustrate the need for integrated studies, when appropriate.

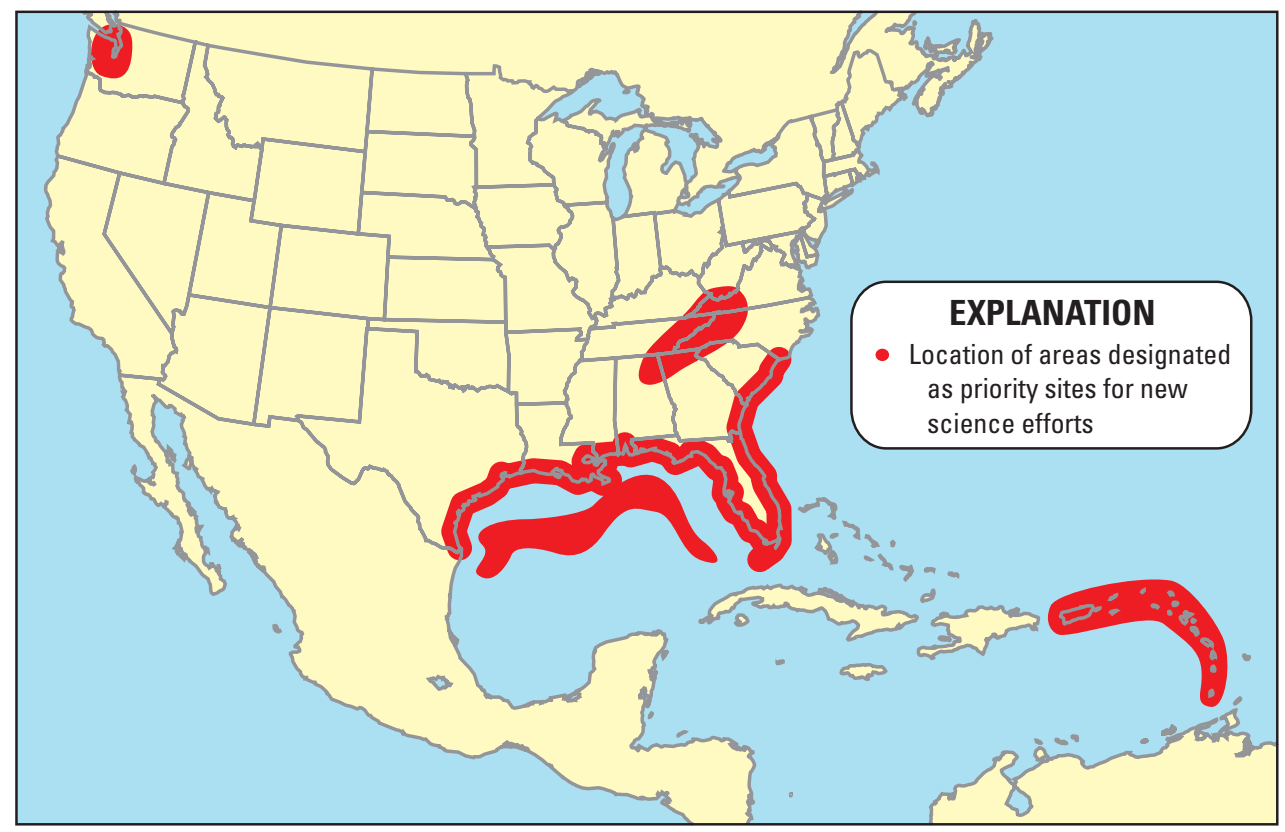

Figure 8. Map showing geographic areas designated as priority sites for new science efforts. 
FISC scientists have identified several geographic areas as priority sites for new science efforts (fig. 8):

- Appalachian Mountains (e.g., biodiversity assessment).

- Caribbean (e.g., coastal lidar surveys; coral reef ecosystems; water availability.

- Florida Keys and Florida Shelf (e.g., urban impacts on water quality and ecosystems, coral reef deterioration, leaky margins, African dust impacts).

- Florida panhandle (e.g., saltwater intrusion; urbanization-induced habitat change; water availability).

- Gulf of Mexico (e.g., deep-water reef environments-biodiversity, mapping, ecosystem history, trawling/ drilling impacts, hypoxia).

- Puget Sound (e.g., urbanization-induced habitat change)

- Southeastern estuaries (e.g., geologic controls on ground-water flow; leaky coastal margins).

- Ten Thousand Islands (e.g., wetland change; leaky coastal margins; sea level).

\section{New Scales}

Future science directions should increase our capacity to expand on traditional site-specific and discipline-specific studies. For example, studies could be spatially expanded in scale from small geographic areas to larger regional or global areas. Studies of critical resources (such as ground- and surface waters, wetlands, coastal waters, estuaries, and coral reefs) could integrate geological, chemical, paleoecological, and biological processes, and address global as well as regional issues. The studies might cover such issues as climate change, sea-level rise, natural hazards, as well as direct anthropogenic impacts such as the effects of contaminants and nutrients on ecosystems, decline and extinction of native species, and the effects of microbial pathogens on natural systems and humans.

Future science directions should also increase our capacity to expand or contract study timescales to address long-term trends such as those that occur over decades, or short-term (hours to days) effects such as impacts of storms or hurricanes (through rapid response actions).

FISC scientists have identified the following areas of research as priorities for future science efforts:

- Develop techniques to expand understanding of ecosystem history and prediction (e.g., characterize the pre-development Everglades and predict how restoration might lead to similar or to desired predevelopment conditions).

- Establish spatial linkages among disciplines (e.g., colocation of data gathering and databases for geology, biology, and water, integrative modeling within a basin).

- Improve our ability to study and document catastrophic events in the environment through rapid-response tactics and new technologies (e.g., What are the immediate effects of fires, hurricanes, or droughts on water quality? How can we better use remote sensing to monitor rapid environmental changes on a nearreal-time basis?).

- Increase our capacity to modify the spatial and temporal scale of studies (e.g., What are the environmental effects of inter-basin transfers of water, such as is being proposed between the northern and southern parts of Florida? ).

- Integrate remote-sensing capabilities with quantitative process studies to scale upward from the study site or local scale to regional models of key ecosystem functions.

\section{New Technologies}

Productive collaboration between scientists and engineers has led to new capabilities in measuring and visualizing previously unobservable environmental quantities and phenomena. On the smallest of scales, advances in miniaturization (e.g., microelectromechanical systems, MEMS) have led to new instrumentation capable of measuring environmental quantities with unprecedented sensitivity in previously inaccessible environments. At intermediate spatial scales, new developments in airborne lidar technology are revolutionizing not only our view of Earth features with topographic expression (e.g., earthquake faults, coral reefs), but also our ability to model processes with a topographic dependence (e.g., barrier island storm response, tsunami susceptibility). Novel geophysical techniques (e.g., streaming resistivity) are providing new insight into hydrogeological controls on coastal processes. On yet larger spatial scales, high-resolution satellite images offer the possibility of scaling up point measurements (e.g., evapotranspiration, benthic production) to landscape scales. At every scale, realtime data telemetry is an important component. Building on in-house expertise and existing collaborations with technical agencies (e.g., NASA), FISC scientists are particularly well positioned to take advantage of new developments in the following priority areas:

- Acoustic and optical technologies (e.g., phase arrays for flow monitoring, surrogates for suspended sediment, ground-water saline encroachment);

- Lidar and other remote-sensing technologies (e.g., submarine topography, determining the land/water interface); 
- Miniaturization (e.g., in situ measurements of volatile organic compounds);

- Molecular biology and biochemical analyses of microbial communities (e.g., source tracking of contaminants in water and in atmospheric particulates);

- Real-time water-quality and quantity telemetry for web-based applications (e.g., sediment resuspension);

- Streaming resistivity (e.g., submarine ground-water discharge);

- Surface and borehole geophysics (e.g., determining preferential flow zones, sequence stratigraphy).

\section{Superstations}

Current ecological research requires ever-increasing integration of scientific disciplines and data collection. An approach that is not new, but that is as yet under-exploited in the context of FISC research, is a superstation, i.e., the colocation of environmental, ecological, and physical sampling so that inference across scale and discipline can be made. Currently, data are difficult to relate from one site to another limiting the ability to construct models, test hypotheses, and discern relations among differing datasets. In the future, knowledge of planned investigations and data collections on any science issue or location can ideally be exchanged such that co-location of sampling and projects can occur. This approach will require organization, new technology, and true integration of time and resources within FISC and with our partners.

An example of this approach that could have immediate impact concerns ecological and hydrologic research and data collection in south Florida. To date, data collection for ecological research of fish, alligators, and other species is planned based on statistical procedures that stratify samples by habitat, population parameters, or logistical constraints. Hydrologic monitoring stations have been erected based on specific flow patterns, partner needs, and political boundaries. These overlapping but uncoordinated planning efforts have led to a duplication of data-collection efforts and lack of data required for specific modeling efforts or decision making. For example, Biology Discipline ecologists measure water depths on their own collection sites due to the distance to Water Discipline hydrologic stations. These additional data are then not added to the hydrologic databases but used to make inferences only about the species of interest. However, implementation of organized efforts to co-locate sampling or to provide waterdepth sampling protocols and training across disciplines could provide a cost savings to each individual project.

Future efforts could incorporate many types of data collection into a single site including biological sampling (species monitoring, (capture-recapture, condition, contaminant loads), hydrologic sampling (flows, salinity, conductiv- ity), geochemical sampling (atmospheric deposition), geologic data collections (geophysical logging, land subsidence), and geographical studies (photography, ground-truthing).

FISC scientists have identified the following superstations (for site-specific studies and as networks) as priorities for future science efforts:

- Coastal-monitoring network (e.g., participate in Oceans/ U.S. Coastal Observing System; evaporation, wind movement, surface-water flux to coastal areas).

- Everglades restoration (e.g., , co-location of biological, hydrologic, and geologic sampling).

- Freshwater-spring studies (e.g., new studies focusing research including all FISC disciplines on particular springs and questions).

- Stream-gaging and ground-water surveillance network (e.g., add biologic and geologic sampling at current sites).

\section{REFERENCES}

Beggs, D., 1999, Liberating ecological reason through interdisciplinarity: Metaphilosophy 30: 186-208.

Blanchard, S.F., 1999, External Task Force Review of the U.S. Geological Survey Federal-State Cooperative Water Program, August, 1999: U.S. Geological Survey Circular 1192. http://water.usgs.gov/pubs/circ/circ1192/

Collins, J.P., 2002, May you live in interesting times: Using multidisciplinary and interdisciplinary programs to cope with change in the life sciences: BioScience 52: 75-83. http://www.msu.edu/user/gradschl/es/pubs/collins.pdf

Gossman, D.G., 1979, A quantitative system for the assessment of initial organizational needs in transdisciplinary research: M.S. Thesis, Michigan State University, http:// gossman.org/daveg/thctoc.htm

Katz, B.G., Griffin, D.W., Swarzenski, P.W., Walsh, S.J., and Jelks, H.L. 2003. Florida springs interdisciplinary science study. U.S. Geological Survey Fact Sheet FS-008-03, 4 p.

National Research Council, 2001, Future Roles and Opportunities for the U.S. Geological Survey: Washington, DC: National Academy Press (http://books.nap.edu/ books/0309072646/html/index.html) .

Workshop Staff, 1998, Summary Report of the Workshop on Enhancing Integrated Science, November 4-5, 1998, Reston, Virginia: Sponsored by the U.S. Geological Survey, Geological Society of America, and the Ecological Society of America. 


\section{APPENDIX 1: CHARGE TO SCIENCE COUNCIL}

\section{Charge to Science Council Florida Integrated Science Center January 16, 2003}

As a group of distinguished scientists, you were selected to represent the breadth of the USGS disciplines and the vast scope of USGS expertise focused, not only on natural science issues of Florida, the Gulf Coast, and southeast, but the U.S. southeast coastal ocean, the Great Lakes, and other coastal areas and topical issues.

You are charged with developing and maintaining a longterm strategic science plan for the Florida Integrated Science Center (FISC). The FISC Science Plan will align with the priorities of the Eastern Region Science Plan and the strategic goals identified within the Bureau's Future Science Directions and the Discipline Strategic Plans. It will enable the FISC to participate effectively in the Bureau program-planning process. The FISC Science Plan will provide a vision for sustainable research for FISC. Science integration will be the priority, as appropriate. Relationships and dependencies upon partners will be identified. The science plan will provide clear direction on how the FISC Program will:

- Fulfill its mission responsibilities regionally, nationally, and globally;

- Set priorities for funding integrative and topic-specific projects;

- Establish methods for reviewing scientific accomplishments;

- Enhance scientific capabilities; and

- Identify training needs.

As you develop the plan, be cognizant of new and innovative funding opportunities, and the means to support and enhance existing reimbursable activities.
Follow-on activities:

In support of the science plan, the FISC Science Council is charged with developing a workforce skills plan. This plan will identify existing science skills and capabilities, gaps that are identified through the science-planning process, and recommendations to acquire the skills necessary to close the identified gaps. In addition to limited critical hires, the recommendations can include methods such as sharing workforce across Center and regional boundaries, collaboration with Cooperative Ecosystem Study Units, and collaboration with universities and other Federal agencies.

Additionally, the FISC Science Council is charged with working with the Regional Communication Officer, Michelle Barret, to develop a Communication Plan about the science plan. The Communication Plan will be congruent with the Eastern Region Communication Plan and will identify key customers (internal and external), their information needs, vehicles for delivering messages (news releases, exhibit booths, community fairs, etc.) and a time schedule.

\section{Charge to FISC Science Council}

Timetable:

- First draft due to the ERLT on April 24, 2003, following appropriate review by the FISC Board of Directors and Executive Committee

- Discussions with Project Chiefs and subsequent modifications due by May 30, 2003

- Review of plan by partners completed by July 11, 2003

- Completion of FISC Science Plan by August 1, 2003

- Development of annual review and revision plan through March 2008, due by August 15, 2003

- Draft Communication Plan due August 29, 2003 


\section{APPENDIX 2: DEFINITIONS OF DISCIPLINE INTEGRATION}

For the purpose of characterizing research currently being conducted by FISC scientists, the Science Council adopted the following "levels of integration" classification scheme:

Discipline-specific research is carried out by one or more individuals within a single discipline -- i.e., within a body of knowledge or branch of learning characterized by an accepted content (Gossman, 1979; Beggs, 1999; Collins, 2002). When conducting disciplinary research, investigators draw on the methods and theories of a single well-defined specialization, with the goal being a deep understanding of a single problem or a single aspect of a problem (Workshop Staff, 1998). FISC examples include Florida stream gaging (Water), studies of fish taxonomy (Biology), assessments of sand resources (Geology), and long-term land-cover characterizations (Geography).

Multidisciplinary research mingles disciplines but maintains their distinctiveness (Beggs, 1999; Collins, 2002). When participating in multidisciplinary research, investigators from two or more disciplines work together on a common problem but with limited interaction. The cooperating researchers typically do not jointly design experiments, analyze results, and publish together (Beggs, 1999; Collins, 2002). The goal of multidisciplinary research is a broader understanding of a problem or question, based on the combined results of disciplinary investigations (Workshop Staff, 1998). FISC examples include TIME/SIC modeling (Water, Biology), portions of Place-Based Studies in Florida (Biology, Geography, Geology, Water), and the Coral Reefs projects (Biology, Geology).

Integrated research focuses on major issues that cross the narrow boundaries of conventional scientific disciplines and is more than simply a multidisciplinary collaboration, although it may begin there (National Research Council, 2001). Termed integrative science by the National Research Council (2001):

"It involves individuals sharing different perspectives, methodologies, and conceptual models in a manner that changes each person's approach to the problem at hand. An integrative approach to science entails a focus on problems in all of their complexity, and the creation of teams with the skills and resources necessary to provide the entire suite of knowledge required for solutions or at least for well-informed responses."
Akin to the 'interdisciplinary' category of Collins (2002):

"Practically speaking, completing the project requires the joint effort of investigators from two or more disciplines. Consequently, collaborative experiments, analysis, and publication are often the product. Integrating the diverse expertise of the participants is the key to success."

Examples of integrated science projects include Aquatic Cycling of Mercury (Biology, Water; http://sofia.usgs. gov/projects/evergl_merc), the Tampa Bay Integrated Science project (Biology, Geography, Geology, Water; http://gulfsci. usgs.gov/tampabay), and Land Characterization from Remote Sensing (Biology, Geography, Water).

To interpret the survey of FISC research based on the "levels of integration" classification scheme properly (Section II), several additional caveats and considerations must be kept in mind:

- The above classes - disciplinary, multidisciplinary, and integrated-represent not discrete categories, but rather overlapping descriptors along a continuum.

- Because research investigations are structured differently within the different Disciplines, it is not possible to compute an accurate and precise estimate of the number of funded investigations within each of the above categories. Summary results are expressed in terms of total FY2003 dollars.

- Some large, multi-investigator projects consist of many Tasks and Sub-Tasks, some of which are appropriately discipline-specific and some of which are being conducted in a multidisciplinary or integrative manner. Rather than categorizing each individual Task as to its "degree of integration," a single best-guess designation was assigned to the entire project.

- In some instances, collaborative research is being conducted in a way that meets the operational definition of integrated science, but not within the confines of a single project. Rather, individual investigators are each bringing their own project dollars to the table and expending them in a cross-Discipline integrative manner. In these instances, each of the participating projects was assigned an "integrated" designation.

- While support functions (e.g., South Florida Information Access, SOFIA) provide important services, the summaries focus only on research investigations. 


\section{APPENDIX 3: FISCAL YEAR 2004 COOPERATOR LIST FOR FISC}

\section{LOCAL AND STATE COOPERATORS}

\author{
ALACHUA COUNTY ENVIRONMENTAL \\ PROTECTION \\ GAINESVILLE, FL
}

BROWARD COUNTY WATER RESERVE

MANAGEMENT DIVISION

POMPANO BEACH, FL

CITY OF BOCA RATON

BOCA RATON, FL

CITY OF BRADENTON

BRADENTON, FL

CITY OF CAPE CORAL

CAPE CORAL, FL

CITY OF COCOA

COCOA, FL

CITY OF HALLANDALE

HALLANDALE, FL

CITY OF HOLLYWOOD

HOLLYWOOD, FL

CITY OF JACKSONVILLE

JACKSONVILLE, FL

CITY OF SARASOTA

SARASOTA, FL

CITY OF TALLAHASSEE

TALLAHASSEE, FL

CITY OF TALLAHASSEE ELECTRIC DEPARTMENT

TALLAHASSEE, FL

CITY OF TALLAHASSEE WATER QUALITY LAB

TALLAHASSEE, FL

CITY OF TAMPA

TAMPA, FL

DESOTO COUNTY

ARCADIA, FL
FLORIDA DEPARTMENT OF AGRICULTURE AND CONSUMER SERVICES

TALLAHASSEE, FL

FLORIDA DEPARTMENT OF ENVIRONMENTAL PROTECTION

TALLAHASSEE, FL

FLORIDA DEPARTMENT OF TRANSPORTATION

TALLAHASSEE, FL

FLORIDA FISH \& WILDLIFE CONSERVATION COMMIS-

SION

TALLAHASSEE, FL

FLORIDA KEYS AQUEDUCT AUTHORITY

KEY WEST, FL

FLORIDA STATE UNIVERSITY

TALLAHASSEE, FL

HILLSBOROUGH COUNTY

TAMPA, FL

JACKSONVILLE ELECTRIC AUTHORITY

JACKSONVILLE, FL

LEE COUNTY PUBLIC WORKS BUILDING

FORT MYERS, FL

MANATEE COUNTY

BRADENTON, FL

MIAMI-DADE COUNTY DEPARTMENT OF

ENVIRONMENTAL RESOURCES

MIAMI, FL

MIAMI-DADE COUNTY WATER AND SEWER

DEPARTMENT

MIAMI, FL

NASSAU COUNTY FLORIDA

YULEE, FL

NORTH PORT WATER CONTROL DISTRICT NORTH PORT, FL

NORTHWEST FLORIDA WATER MANAGEMENT

DISTRICT

HAVANA, FL

OKALOOSA COUNTY

SHALIMAR, FL 
OKLAWHA BASIN RECREATIONAL

WATER CONSERVATION CONTROL AUTHORITY

TAVARES, FL

ORANGE COUNTY UTILITIES

ORLANDO, FL

PEACE RIVER MANASOTA REGULATION

WATER SUPPLY AUTHORITY

BRADENTON, FL

PINELLAS COUNTY

CLEARWATER, FL

POLK COUNTY

BARTOW, FL

REEDY CREEK IMPROVEMENT DISTRICT LAKE BUENA VISTA, FL

SANTA ROSA COUNTY

MILTON, FL

SEMINOLE COUNTY, PUBLIC WORKS

SANFORD, FL

SEMINOLE TRIBE OF FLORIDA

HOLLYWOOD, FL

SOUTH FLORIDA WATER

MANAGEMENT DISTRICT

WEST PALM BEACH, FL

SOUTHWEST FLORIDA WATER

MANAGEMENT DISTRICT

BROOKSVILLE, FL

ST. JOHNS RIVER WATER

MANAGEMENT DISTRICT

PALATKA, FL

SUWANNEE RIVER WATER

MANAGEMENT DISTRICT

LIVE OAK, FL

TAMPA BAY WATER

CLEARWATER, FL

UNIVERSITY OF FLORIDA

GAINESVILLE, FL

UNIVERSITY OF SOUTH FLORIDA

TAMPA, FL

VOLUSIA COUNTY FINANCE DEPARTMENT

DELAND, FL
WALTON COUNTY EMERGENCY MANAGEMENT

DEFUNIAK SPRINGS, FL

\section{OTHER FEDERAL AGENCY CUSTOMERS}

CORPS OF ENGINEERS ENVIRONMENTAL BRANCH JACKSONVILLE, FL

CORPS OF ENGINEERS

JACKSONVILLE, FL

DEFENSE FINANCE ACCOUNTING SYSTEM

CHARLESTON, SC

DEPARTMENT OF DEFENSE CORPS OF ENGINEERS JACKSONVILLE, FL

DEPARTMENT OF THE NAVY, SOUTHERN DIVISION NAVAL FACILITIES ENGINEERING COMMAND NORTH CHARLESTON, SC

EGLIN AIR FORCE BASE

EGLIN AFB, FL

FISH \& WILDLIFE SERVICE

ATLANTA, GA

NATIONAL BIOLOGICAL INFORMATION

INFRASTRUCTURE

KAHULUI, HI

NATIONAL BIOLOGICAL INFORMATION

INFRASTRUCTURE

RESTON, VA

NATIONAL OCEANIC AND ATMOSPHERIC

ADMINISTRATION

ANN ARBOR, MI

NATIONAL OCEANIC AND ATMOSPHERIC

ADMINISTRATION

SILVER SPRING, MD

NATIONAL PARK SERVICE

ATLANTA, GA

NATIONAL PARK SERVICE

CENTER FOR URBAN ECOLOGY

WASHINGTON, DC

NATIONAL PARK SERVICE

EVERGLADES NATIONAL PARK

HOMESTEAD, FL 
NATIONAL PARK SERVICE

FORT COLLINS, CO

NATIONAL PARK SERVICE

HERNDON, VA

SMITHSONIAN ENVIRONMENTAL RESEARCH

CENTER

EDGEWATER, MD

U.S. ARMY CORPS OF ENGINEERS

MILLINGTON, TN

U.S. DEPARTMENT OF AGRICULTURE

BELTSVILLE, MD

\author{
U.S. ENVIRONMENTAL PROTECTION AGENCY \\ CINCINATTI, OH
}

U.S. FISH AND WILDLIFE

PANAMA CITY, FL

U.S. FISH AND WILDLIFE SERVICE

ARLINGTON, VA

U.S. FISH AND WILDLIFE SERVICE

DENVER, CO

\section{APPENDIX 4: BACKGROUND DOCUMENTS}

USGS Future Science Directions

http://internal.usgs.gov/director/fsd/

Eastern Region Science Plan, Executive Summary (draft)

http://internal.usgs.gov/er/docs/SciPlan_exSum3.0.doc

Florida Integrated Science Center Information Sheet

http://fisc.er.usgs.gov/Sci_Flier_P_3-31.pdf

Strategic plans for individual Disciplines are located online at:

Biological Resources Division Strategic Science Plan

http://biology.usgs.gov/science/strategicplan.html

Geology for a Changing World: A Science Strategy for the Geologic Division of the U.S. Geological Survey http://pubs.usgs.gov/circ/c1172/

Strategic Directions for the Water Resources Division, 1998-2008

http://water.usgs.gov/pubs/of/ofr99-249/

Strategic Plan for the Water Discipline of the U.S. Geological Survey in Florida http://fl.water.usgs.gov/PDF_files/ofr01_180_hammett.pdf

Strategic Plan for the National Mapping Division of the U.S. Geological Survey http://mapping.usgs.gov/misc/strategic.html 